\title{
Review: Epidemiological evidence of groundwater contribution to global enteric disease, 1948-2015
}

\author{
Heather Murphy \\ Temple University, heather.murphy@temple.edu \\ Morgan Prioleau \\ Temple University \\ Mark Borchardt \\ USDA / USGS Marshfield, Wisconsin
}

See next page for additional authors

Follow this and additional works at: https://arrow.tudublin.ie/ehsiart

Part of the Environmental Health Commons, and the Medicine and Health Sciences Commons

\section{Recommended Citation}

Murphy, Heather \& Prioleau, Morgan \& Borchardt, Mark \& Hynds, Paul. (2017). Epidemiological evidence of groundwater contribution to global enteric disease, 1948-2015. Hydrogeology Journal. 25. 10.1007/ s10040-017-1543-y.

This Article is brought to you for free and open access by the ESHI Publications at ARROW@TU Dublin. It has been accepted for inclusion in Articles by an authorized administrator of ARROW@TU Dublin. For more information, please contact arrow.admin@tudublin.ie, aisling.coyne@tudublin.ie,gerard.connolly@tudublin.ie.




Authors

Heather Murphy, Morgan Prioleau, Mark Borchardt, and Paul Hynds

This article is available at ARROW@TU Dublin: https://arrow.tudublin.ie/ehsiart/35 
See discussions, stats, and author profiles for this publication at: https://www.researchgate.net/publication/315383752

\section{Epidemiological evidence of groundwater contribution to global enteric disease, $1948-2015$}

Article in Hydrogeology Journal · March 2017

DOI: 10.1007/s10040-017-1543-y

CITATIONS

33

4 authors, including:
Heather M. Murphy

University of Guelph

53 PUBLICATIONS 768 CITATIONS

SEE PROFILE
703

Paul D Hynds

Technological University Dublin - City Campus

115 PUBLICATIONS 720 CITATIONS

SEE PROFILE

Some of the authors of this publication are also working on these related projects:

Risk, awareness, perceptions, and behaviours pertaining to the adverse human health effects of previous and future flood events in Ireland (FloodRisk2WellWater) View project

Knowledge to Practice with the Global Water Pathogens Project View project 


\title{
Review: Epidemiological evidence of groundwater contribution to global enteric disease, 1948-2015
}

\author{
Heather M. Murphy ${ }^{1}$ Morgan D. Prioleau ${ }^{1} \cdot$ Mark A. Borchardt $^{2} \cdot$ Paul D. Hynds $^{3}$
}

Received: 6 September 2016 / Accepted: 13 January 2017 /Published online: 18 March 2017

(C) Springer-Verlag Berlin Heidelberg 2017

\begin{abstract}
Globally, approximately 2.2 billion people rely on groundwater for daily consumption. It is widely accepted that groundwater is more pristine than surface water but while this assumption is frequently the case, groundwater is not ubiquitously free of contaminants; accordingly, this presumption can result in an unfounded and potentially hazardous sense of security among owners, operators and users. The current paper presents a review of published literature providing epidemiological evidence of the contribution of groundwater to global human enteric infection. An emphasis is placed on enteric pathogens transmitted via the faecal-oral route, and specifically those associated with acute gastrointestinal illness (AGI). The review identified 649 published groundwater outbreaks globally between 1948 and 2013 and several epidemiological studies that show there is an increased risk of AGI associated with the consumption of untreated groundwater. The review identified that the following five pathogens were responsible for most outbreaks: norovirus, Campylobacter, Shigella, Hepatitis A and Giardia. Crudely, the authors estimate that between 35.2 and 59.4 million cases of AGI per year globally could be attributable to the consumption of groundwater. Although groundwater is frequently presumed to be a microbiologically safe source of water for consumption, this
\end{abstract}

Published in the special issue "Hydrogeology and Human Health"

Heather M. Murphy

heather.murphy@temple.edu

1 Division of Environmental Health, College of Public Health, Temple University, Philadelphia, PA, USA

2 USDA/ USGS Marshfield, Wisconsin, USA

3 Environmental Health and Sustainability Institute, Dublin Institute of Technology, Dublin, Republic of Ireland review demonstrates that consumers served by an untreated groundwater supply remain at risk to enteric disease. The authors conclude that collaboration between microbiologists, hydrogeologists and epidemiologists is needed to better understand pathogen occurrence, persistence, detection and transport in groundwater as well as build stronger epidemiological evidence documenting the true magnitude of disease associated with groundwater globally.

Keywords Health · Enteric disease · Global · Epidemiology · Pathogens

\section{Introduction}

Groundwater is the world's most extracted raw material, both in terms of frequency and volume, with global withdrawals currently estimated to be $982 \mathrm{~km}^{3} /$ year (Margat and van der Gun 2013). Globally, the authors estimate that approximately 2.2 billion people (31.5\% of the global population) rely on groundwater for daily consumption. In the United States, 90.5 million people are served by community groundwater systems, while 48 million people have a private well (Colford et al. 2006a, b; US EPA 2015). In Canada, 4.1 million (11.7\%), 2.6 million (7.4\%) and $>1$ million people (3.1\%) are reliant on private wells, large municipal groundwater systems ( $>1,000$ people), and small municipal groundwater systems ( $<1,000$ people), respectively (Murphy et al. 2016a, b). Analogous figures pertaining to Asia, Europe, Latin America and Australia are 1-1.2 billion, 200-500 million, 150 million, and 3 million people, respectively (Job 2009). A further $80 \%$ of the 900 million people in Africa (720 million people) employ a groundwater source (Macdonald et al. 2009).

It is widely accepted that groundwater typically represents a more pristine source of water for human consumption than 
surface-water resources, due to the inherently protective effects afforded by overlying soil and subsoil layers-i.e. increased residence times, physical, chemical and microbial attenuation, etc. (Medema et al. 2003). While this assumption is frequently the case, groundwater is not ubiquitously free of chemical and/or microbial contaminants; accordingly, this presumption can result in an unfounded and potentially hazardous sense of security among owners, operators and usersfor example, in an effort to reduce waterborne gastrointestinal illness in developing regions of southern Asia, the international community heavily promoted a shift from using surface water to presumably cleaner groundwater sources during the 1970s (Flanagan et al. 2012). However, at the time, high rates of naturally occurring arsenic via concurrent biogeochemical and hydrologic processes in many of these regions had not been recognized, resulting in a widespread failure to assess the chemical quality of newly developed groundwater sources (Mukherjee et al. 2006).

Similarly, in developed regions, the presumption that groundwater is a universally safe resource has resulted in undesirable practices; recent studies of private well users in Ireland, Canada and the US have found a concurrence between the belief that groundwater represents a safe domestic water supply, and a lack of "protective action" by homeowners (i.e. source maintenance, periodic testing, water treatment; Strauss et al. 2001; Charrois 2010; Kreutzwiser et al. 2011; Hynds et al. 2013). In a survey of 245 private well owners in the Republic of Ireland, Hynds et al. (2013) found that water treatment, source maintenance and regular water quality testing were absent in 64, 72 and $40 \%$ of cases, respectively. Moreover, globally, at the governmental level, it is important to note that private groundwater sources remain unregulated in many provinces, states and countries.

Groundwater represents a significant source of potentially hazardous microbial pathogens, with subsurface pathogen occurrence, distribution and movement still poorly understood in many areas and environments. The body of evidence in the academic literature leaves little doubt that contaminated groundwater supplies are a significant source of endemic, sporadic, and epidemic gastrointestinal infections in both developed and developing regions (Gallay et al. 2006; Fong et al. 2007; Craun et al. 2010; Kvitsand and Fiksdal 2010; Giammanco et al. 2014; Guzman-Herrador et al. 2015; Lapworth et al. 2015). Between 1971 and 2008, approximately $30 \%$ of waterborne outbreaks in the US were associated with consumption of untreated groundwater, with these confirmed events responsible for at least 23,478 infections, 390 hospitalizations, and 13 deaths (Wallender et al. 2014). Just under $18 \%$ of all waterborne outbreaks occurring in Canada between 1974-2001 were associated with contaminated private water supplies, the majority of which rely on groundwater (Schuster et al. 2005; Murphy et al. 2016a). During the 22year period 1989-2011, 76\% of reported outbreaks with a known water source in the Nordic region were related to a public or private groundwater supply (Guzman-Herrador et al. 2015).

The current paper presents results arising from a scoping global review of the available published literature comprising epidemiological evidence of the contribution of groundwater consumption to human infection, with an emphasis placed on enteric pathogens transmitted via the faecal-oral route, and specifically those associated with acute gastrointestinal illness (AGI). Within the published literature, the clinical definition of AGI has been characterized by a relatively wide range of symptoms and severity; for the purposes of the current study, it has been defined as the occurrence of three or more loose stools and/or vomiting over the course of one 24-h period (Murphy et al. 2014). In the interests of clarity, the review has been delineated into three distinct sections, as follows:

1. Global outbreaks with a confirmed groundwater etiology

2. Previous epidemiological studies linking enteric (epidemic and endemic) disease to public or private groundwater sources

3. The occurrence of enteric pathogens in groundwater (including wells and aquifers) and associated microbial risk assessment

It should be noted that while every effort was made to identify and include all relevant global studies, due to myriad limitations including potential publication bias and infrastructural or economic deficiencies per issue, a number of regions are likely over-represented, namely North America and Europe.

\section{Groundwater supply types: public groundwater systems and private wells}

At present, groundwater used for drinking is typically provided via municipal supplies overseen by a local authority, local committee-managed community water systems or privately owned and managed wells. All of these groundwater supply types may or may not be treated depending on the context and local, regional or national regulations. In developing countries, wells may be shared by communities or individually owned and, typically, undergo no treatment at the source (WHO/UNICEF JMP 2015). The primary distinction between municipal, community and private supplies are the regulatory frameworks within which they are managed. In developed countries such as in Canada, the United States and many European countries, private groundwater supplies remain unregulated and it is therefore the homeowner's responsibility to maintain and manage their water supply (Atherholt et al. 2013; Murphy et al. 2016a; Irish Environmental Protection Agency 2016). In 
the Republic of Ireland, a private borehole (or dug well) remains the only significant feature of a domestic residence, which is not regulated by any legislative instrument or standard (Ball 2000). Regulatory frameworks that define a private well, versus a public or community based groundwater system varies greatly from country to country; therefore, it is difficult to make comparisons. Globally, limited data are available on the proportion of private well owners that test their water annually, the proportion that treat their water prior to consumption, and the types of treatment systems used in these households. In Canada, 34\% of private well owners reported that they treated their water for bacteria; however, it is unclear what type of treatment system these homeowners had in place (Statistics Canada 2013). In New Jersey, USA between 2002 and 2007, 50,800 domestic wells (out of an estimated 400,000) were tested for total coliforms and faecal coliforms/E. coli (organisms used to suggest contamination of faecal origin). Based on "one-off" sample collection, 13.1 and $2.1 \%$ of wells were positive for total coliforms and faecal coliforms $/ E$. coli, respectively, leading the authors to suggest that up to $13.1 \%$ of private wells in New Jersey were contaminated with faecal pollution at least once during the study period (Atherholt et al. 2012). In a second study in New Jersey, Atherholt et al. (2015) reported that in bedrock, 21,33 and $43 \%$ of wells tested once, twice or three times were positive for total coliforms. Sampling and analyses carried out in Ireland as part of the EPA Groundwater Monitoring Program during the 10-year period 1998-2008 suggests annual mean bacterial contamination (total coliforms, E. coli, faecal coliforms) rates of $25-35 \%$ across the national monitoring network which includes municipal, community, and monitoring wells (US EPA 2015). Subsequent works by Bacci and Chapman (2011) and Hynds et al. (2012) have reported similar rates in private boreholes in the Republic of Ireland.

The regulatory framework of municipal and community managed groundwater varies by country and often by state or province within that country. For instance, in the United States all systems serving $>25$ households or connections are considered community water supplies and are subject to some regulation. The US EPA Groundwater Rule has no explicit disinfection requirements for community groundwater systems unless system deficiencies or source contamination issues have been identified (US EPA 2008). Each state adopts their own version of the Groundwater Rule, which, can be more stringent. In some states, community water supplies utilizing a groundwater source need to be disinfected (e.g. Pennsylvania, New York, West Virginia), whereas in other states, no treatment of these supplies is employed unless the water system has significant deficiencies in terms of water quality (e.g. Washington State, Wisconsin, Florida).

\section{Groundwater-related outbreaks of enteric infections}

In an effort to capture a representative sample of confirmed groundwater-related outbreaks of enteric infection from around the world, over the past three decades a scoping review was undertaken. The NCBI PubMed archive of biomedical and life sciences was searched using the keywords "groundwater" and "outbreak". Overall, 98 articles dating back to 1985 were recovered, of which 94 were in English. Forty-four articles discussed either multiple or single outbreaks related to groundwater and have been included here. The remaining articles were either excluded as they did not pertain to groundwater specifically, or they were retained because they discussed pathogens found in groundwater under non-outbreak conditions and are further discussed in section 'Pathogens of concern in groundwater'. Table 1 summarizes the available literature pertaining to groundwater-related outbreaks of enteric infection stratified by country/region. As shown, the highest number of reported outbreaks were reported in articles from the United States $(n=19)$. The majority of available articles focused on outbreaks in middle and high-income countries, with very little coverage of outbreaks in low-income regions. The breakdown of articles by region was North America $(n=19)$, Europe $(n=13)$, Asia $(n=8)$, Africa $(n=1)$, and the Middle East $(n=1)$.

\section{Pathogens associated with groundwater outbreaks}

Table 2 presents a breakdown of the most frequently reported pathogens with respect to the groundwater-related outbreaks included in the current scoping review. The review identified the following 17 pathogens responsible for groundwater related outbreaks, listed from most to least outbreaks: norovirus (39), Campylobacter (31), Shigella (24), Hepatitis A (21), Giardia (16), Salmonella (12), E. coli O157:H7 (9), Cryptosporidium parvum (7), rotavirus (2), SRSVs (2), Adenovirus (1), Enterovirus (1), Arcobacter (1), Entamoeba (1), Vibrio cholera (1), and Yersinia (1). These outbreaks are further examined in section 'Pathogens of concern in groundwater' where the principal pathogens of concern in groundwater based upon confirmed outbreak etiologies (Table 2) and their occurrence during groundwater surveillance activities are discussed (Table 4). Of those articles included in the current scoping review, which reported on groundwaterrelated outbreaks with a confirmed or suspected etiology, $46 \%$ were associated with bacterial pathogens, $40 \%$ were related to viruses and $14 \%$ were related to protozoa. The likely factors contributing to the higher occurrence of reported outbreaks with a viral or bacterial etiology are their comparatively longer survival outside a host, and their 
Table 1 Published groundwater-related enteric infection outbreaks from 1948 to 2013 stratified by country/region (ordered from most to least outbreaks)

\begin{tabular}{|c|c|c|c|}
\hline Country & $\begin{array}{l}\text { Number of groundwater } \\
\text { outbreaks }\end{array}$ & Period or year & References \\
\hline United States & $\sim 386$ & $1948-2011$ & $\begin{array}{l}\text { Adam 2016; Balbus and Embrey 2002; Barwick et al. 2000; } \\
\text { Beer 2015; Blackburn 2004; Borchardt et al. 2011a; Casemore 2006; } \\
\text { Craun 1992; Craun et al. 2010; Curriero et al. 2001; Fong et al. 2007; } \\
\text { Herwaldt et al. 1991; Moore 1993; Parshionikar et al. 2003; } \\
\text { Reynolds et al. 2008; Rose 1997; Straub et al. 1993; Wallender et al. } 2014\end{array}$ \\
\hline Scandinavia $^{\mathrm{a}}$ & 139 & $1984-2012$ & $\begin{array}{l}\text { Guzman-Herrador et al. 2015; Hänninen et al. 2003; Jakopanec et al. 2008; } \\
\text { Kukkula et al. 1997; Kvitsand and Fiksdal 2010; Miettinen et al. } 2001\end{array}$ \\
\hline Israel & $\sim 52^{\mathrm{b}}$ & 1976-1997 & Tulchinsky et al. 2000 \\
\hline South Korea & 35 & 1999-2012 & $\begin{array}{l}\text { Cho et al. 2014; Jung et al. 2015; Kim et al. 2005; Koh et al. 2011; } \\
\text { Lee et al. 2011 }\end{array}$ \\
\hline European Union $^{\mathrm{c}}$ & 24 & $1990-2005$ & Risebro et al. 2007 \\
\hline Taiwan & 1 & 1998 & Jean et al. 2006 \\
\hline India & 2 & 2004-2010 & Datta et al. 2012 \\
\hline UK & 2 & $1992-1993$ & Bridgman et al. 1995; Willocks et al. 1998 \\
\hline Italy & 2 & 2003-2011 & Giammanco et al. 2014; Migliorati et al. 2008 \\
\hline France & 1 & 2000 & Gallay et al. 2006 \\
\hline Malaysia & 1 & 2013 & Muhamad Harish et al. 2015 \\
\hline South Africa & 1 & 2006 & Bessong et al. 2009 \\
\hline Greece & 1 & 1996 & Alamanos et al. 2000 \\
\hline Switzerland & 1 & 1998 & Maurer and Stürchler 2000 \\
\hline Canada & 1 & 2000 & Auld et al. 2004; Balbus and Embrey 2002 \\
\hline
\end{tabular}

${ }^{\text {a }}$ Included Finland, Norway, Denmark and Sweden

${ }^{\mathrm{b}}$ From community water systems, unclear if all related to groundwater

${ }^{\mathrm{c}}$ Included the United Kingdom (England, Scotland, N. Ireland, Wales), Finland, France, Spain, Sweden, Greece, Germany, Republic of Ireland, Italy, Netherlands

smaller size resulting in lower rates of physical attenuation and higher rates of movement within the subsurface environment, as compared with protozoa (Macler and Merkle 2000).

\section{Reported causes of pathogen occurrence in groundwater during outbreak and non-outbreak conditions}

The confirmed or likely causes attributed to the groundwaterrelated outbreaks included in the current scoping review are summarized in Table 3. In articles pertaining to the detection of enteric pathogens in groundwater irrespective of public health events (Table 4), the suspected sources/causes of pathogen contamination were similar as those presented in Table 3, including septic systems/sewage, agricultural activities, precipitation events, incorrect well construction and/or maintenance, inadequate treatment, and surface-water intrusion (Brooks et al. 2004; Cheong et al. 2009; Giwa et al. 2015; Lee et al. 2011; Ritter and Sibley 2002; van der Hoek et al. 2011). Additionally, Borchardt et al. (2011a) and
Atherholt et al. (2012) have reported that local geological setting, and particularly the presence of fractured bedrocks, likely contributes to the transport of microbial contaminants and faecal indicators to groundwater supplies. A previous study by Hynds et al. (2012) sought to model microbial ingress to private wells situated in diverse hydrogeological settings in the Republic of Ireland; study findings indicate that the modeling clusters (i.e. explanatory variables) of greatest significance were well design parameters (i.e. source protection; $47 \%$ of calibrated variance), location (setback distance and gradient) of the closest septic tank (25.9\%), local geological setting including subsoil permeability and thickness $(23.5 \%)$, and short-term antecedent rainfall (4.7\%). Accordingly, evidence suggests and the authors would tend to agree that the majority of groundwater contamination events, and subsequent human infections, are caused by $>1$ temporal and/or spatial factor. Thus, source contamination may be geographically and/or temporally specific, which should be appropriately reflected in source protection and management strategies. 







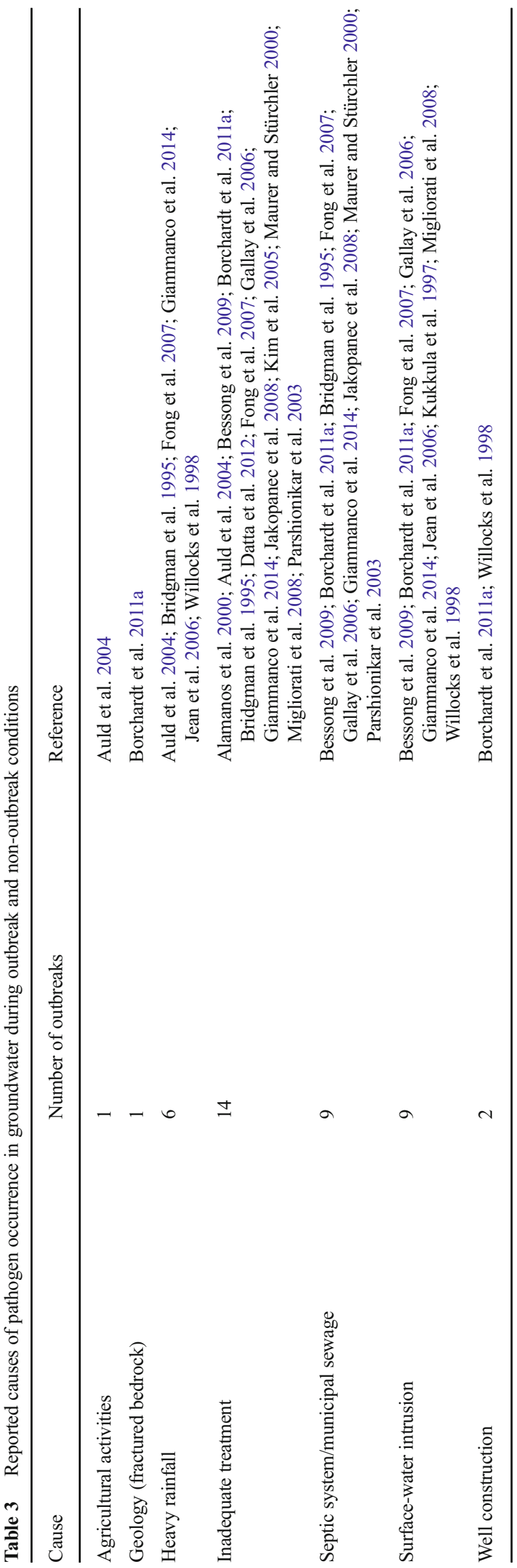

The epidemiology of groundwater-related infections

In epidemiology, disease occurrence is defined at distinct levels; illnesses within the community may be defined as endemic or epidemic (CDC 2012). Endemic disease refers to the constant presence, or prevalence of a disease within a specific population and/or in a particular region. An example of endemic illness is the relatively constant and predictable annual rates of chickenpox (varicella zoster virus) among children in Canada, the UK, and the US (Seward et al. 2008). "Endemic" and "sporadic" are often interchangeably used to describe levels of illness; however, this is not necessarily accurate as sporadic typically refers to low rates of infection which are neither constant nor predictable. Epidemic disease refers to sudden spikes in disease above local endemic levels. The terms epidemic and outbreak are often used interchangeably (CDC 2012).

Upon examination of the published literature, it is clear that endemic, sporadic, and epidemic levels of illness are associated with groundwater sources globally. Outbreak-associated infections are more frequently tracked, and reported within healthcare systems, and are thus more often linked with the causative organism(s) and source(s). Endemic and sporadic disease associated with groundwater supplies are typically much more difficult to track; cases are by definition isolated and more likely associated with healthy adults (i.e. mild gastrointestinal symptoms with low levels or absence of associated sequelae) resulting in frequent self-medication, high levels of under-reporting and/or under-diagnosis (Schuster et al. 2005, Thomas et al. 2013); Guzman-Herrador et al. 2015; Thomas et al. 2013). Furthermore, previous studies have shown evidence of significant disease source and exposure misclassification, particularly with respect to populations served by private water supplies (Jones et al. 2006). Accordingly, the most effective way of quantifying levels of endemic (and sporadic) waterborne infection within a particular region and/or population is by designing and performing appropriate epidemiological studies. The following sections provide a summary of epidemiological study types and the epidemiological and hydrogeological evidence that has been acquired from several published studies (see section 'Epidemiological studies of endemic or sporadic groundwater-related infections').

\section{Epidemiological studies of endemic or sporadic groundwater-related infections}

The global burden of disease associated with contaminated groundwater supplies remains unknown. As mentioned in the previous section, endemic and sporadic cases of AGI not associated with outbreaks are difficult to track for numerous reasons (Hunter et al. 2011; Murphy et al. 2016a; Thomas et al. 2013). Epidemiological studies such as randomized 
Table 4 Pathogens positively identified in groundwater supplies globally (under non-outbreak and outbreak conditions) 1985-2015

\begin{tabular}{|c|c|c|c|}
\hline Name of organism & Countries & $\begin{array}{l}\text { Number } \\
\text { of studies/articles }\end{array}$ & Reference \\
\hline \multicolumn{4}{|l|}{ Bacteria } \\
\hline Arcobacter spp./Campylobacter spp. & France, US/Canada, New Zealand & 5 & $\begin{array}{l}\text { Close et al. 2008; Hynds et al. 2014b; } \\
\text { Tissier et al. } 2012\end{array}$ \\
\hline Clostridium perfringens & South Korea & 1 & Joung et al. 2013 \\
\hline E. coli $\mathrm{O} 157$ (STEC) & South Korea & 4 & Hynds et al. 2014b; Joung et al. 2013 \\
\hline Enteropathogenic E. coli (EPEC) & US/Canada $^{\mathrm{a}}$ & 4 & Hynds et al. 2014b \\
\hline Salmonella spp. & Nigeria, South Korea, US/Canada & 7 & $\begin{array}{l}\text { Giwa et al. 2015; Haznedaroglu et al. 2012; } \\
\text { Hynds et al. 2014b; Joung et al. } 2013\end{array}$ \\
\hline Shigella & Nigeria, South Korea & 2 & Giwa et al. 2015; Haznedaroglu et al. 2012 \\
\hline V. cholerae & Nigeria, Cameroon, England & 3 & Akoachere et al. 2013; Giwa et al. 2015; Koch 2013 \\
\hline \multicolumn{4}{|l|}{ Protozoa } \\
\hline Cryptosporidium spp. & US/Canada ${ }^{a}$ & 7 & Darnault et al. 2003; Hynds et al. 2014b \\
\hline G. lamblia & US/Canada ${ }^{a}$ & 3 & Hynds et al. $2014 b$ \\
\hline \multicolumn{4}{|l|}{ Viruses } \\
\hline Adenoviruses & South Korea, US/Canada ${ }^{a}$ & 6 & Cheong et al. 2009; Hynds et al. 2014b \\
\hline Astroviruses & Slovenia & 1 & Steyer et al. 2011 \\
\hline Echovirus 1 & United States & & Yates et al. 1985 \\
\hline Enteroviruses & South Korea, US/Canada ${ }^{a}$ & 16 & Hynds et al. 2014b; Joung et al. 2013; Lee et al. 2011 \\
\hline Hepatitis A & US/Canada ${ }^{\mathrm{a}}$ & 7 & Hynds et al. 2014b \\
\hline Human enteric viruses & South Korea, US/Canada ${ }^{a}$ & 5 & $\begin{array}{l}\text { Cheong et al. 2009; Fout et al. 2003; } \\
\text { Hynds et al. 2014b }\end{array}$ \\
\hline Noroviruses & South Korea, Slovenia, US/Canada ${ }^{a}$ & 13 & $\begin{array}{l}\text { Cheong et al. 2009; Hynds et al. 2014b; } \\
\text { Joung et al. 2013; Lee et al. 2011; Steyer et al. } 2011\end{array}$ \\
\hline Poliovirus 1 & United States & & Yates et al. 1985 \\
\hline Reovirus & US/Canada ${ }^{a}$ & 2 & Hynds et al. 2014b \\
\hline Rotaviruses & Slovenia, South Korea, US/Canada ${ }^{a}$ & 6 & $\begin{array}{l}\text { Cheong et al. 2009; Hynds et al. 2014b; } \\
\text { Steyer et al. } 2011\end{array}$ \\
\hline
\end{tabular}

${ }^{a}$ Result for the US/Canada extracted directly from Hynds et al. 2014b, some of these results may have been linked to outbreaks

controlled trails (RCTs), community intervention trials, observational, case-control, and ecological investigations are methods that may be used to understand and quantify the health risks associated with the consumption of untreated groundwater. The majority of the epidemiological studies linking groundwater to enteric disease have been conducted in North America, with the most studies conducted in Wisconsin, USA.

\section{Randomized controlled trials}

Randomized controlled trials (RCTs) are considered the "gold standard" of epidemiological studies for determination of causal links; other study designs are limited in their ability to establish clear causality (as opposed to statistical association) between exposure and disease (Rothman 2012). RCTs are extremely time and resource intensive. In these trials, one group of households is randomly assigned to use an in-home intervention such as a household water filter installed under the tap. The other group of households serves as a control group. The two groups of households are, in theory, representative of one another with the only difference being the household water intervention. Under this assumption, the researchers may attribute differences in illness rates between the two groups to the presence or absence of the household intervention being examined (Rothman 2012). To date, no RCT has been undertaken to specifically investigate the burden of illness associated with consumption of untreated groundwater (Murphy et al. 2014), thus representing an important data and knowledge gap to be filled.

\section{Community intervention trials}

Community intervention trials (CITs) are similar in design to RCTs; however, the intervention is assigned at the community level as opposed to the household level. To date, one community intervention trial has been published globally on untreated groundwater supplies (Borchardt et al. 2012). In this trial, 14 untreated public groundwater supplies were selected in Wisconsin, USA, half of which were randomly assigned to be treated with a UV treatment system and half of which remained untreated (Borchardt et al. 2012). At the mid-point (24 weeks) of the study, the intervention was reversed (i.e. untreated wells had UV systems installed, while treated wells had their systems disconnected). Household served by these municipal wells were blinded to the intervention. Borchardt 
et al. (2012) found that a 6-22\% increase in AGI was associated with viral presence (primarily norovirus and enterovirus) in untreated community groundwater supplies in Wisconsin. The fraction of AGI caused by the water supply approached $63 \%$ in children under 5 years old when norovirus was abundant in the water (Borchardt et al. 2012). Community intervention trials of this nature have several advantages over a household intervention trial. Firstly, the entire water supply for the community is altered; therefore, the intervention is more controlled because people who consume water from outside the home (i.e. at work or at school) are still subject to the intervention provided that they stay within the community. In a household intervention trial, it is more difficult to control for the consumption of water outside of the home. Another advantage of a CIT is that blinding of participants at the community level is easier and possibly more reliable as households cannot tamper with the intervention. One disadvantage of the CIT is that private water supplies cannot be evaluated using this approach. In addition, if the intervention occurs at the water treatment plant, it is difficult to control the quality of water reaching the home (i.e. no control for contamination of distribution system or household plumbing). Since only one trial has been published, it is difficult to extrapolate the results to other countries and contexts. More trials are needed to better understand the burden of waterborne disease associated with untreated community water supplies.

\section{Case-control studies}

Case-control studies are designed to determine if a particular exposure is associated with a specific outcome (Lewallen and Courtright 1998). Case control studies can be either retrospective (use existing data) or prospective (collect current or future data) in nature (Rothman 2012). The study design involves the identification of cases (a group known to have the outcome of interest (e.g. AGI) and controls (a group known to be free of the outcome). Subsequently, available pertinent information with respect to individual demographics and exposures are collated and comparatively analyzed to detect (1) which subjects in each group had the exposure(s) of interest (i.e. consumption of untreated groundwater), and (2) whether this exposure is significantly associated with the outcome of interest (i.e. AGI; Lewallen and Courtright 1998).

The authors have identified four prospective case-control studies, which, sought to examine cases of AGI, with consumption of untreated groundwater included as an exposure of interest. In a study of children aged $\leq 18$ years in Wisconsin, found that $11 \%$ of cases characterized by diarrhoea were directly attributable to consumption of private well water containing faecal enterococci (a faecal indicator organism; Adjusted OR, 6.18; 95\% CI, 1.22-31.46). Similarly, (Denno et al. 2009) found that infection with Salmonella spp. was associated with consumption of private well water in
Washington State [OR $6.5(1.4-29.7)]$. Fullerton et al. (2007) found that infants aged 0-6 months were at risk to Campylobacter infection if they were drinking well water in US case control study (OR 4.4; CI 1.4-14). In another nested case control study conducted in a metropolitan area in the US it was found that there was an increased risk of getting AGI when a household was served by well water compared to surface water (aOR 1.38; CI 1.01-1.87; Gorelick et al. 2011).

\section{Ecological studies}

Ecological studies represent an observational (i.e. no intervention) approach characterized by $\geq 1$ variable being measured at the group (not individual) level-for example, incidence rates of likely or confirmed waterborne infection. Studies may be undertaken either retrospectively or prospectively, with groups/populations typically defined either geographically or temporally. Potential exposures (e.g. drinking water source, rainfall, livestock density, etc.) and outcomes (e.g. AGI incidence) are averaged within each examined population and comparatively analyzed using statistical methods such aslogistic regression, spatial autocorrelation, clustering, principal components analysis, and factor analysis (Craun and Calderon 2006). Disease/infection occurrence is thus compared between populations characterized by differing levels of spatial and/or temporal exposure. Ecological studies are frequently and most appropriately employed for initial investigation of causal hypotheses, particularly where existing relevant data are available (Craun and Calderon 2006). One weakness of ecological studies is that one cannot draw conclusions for individuals, as the data is analyzed at a group level (ecological fallacy). Perhaps the most famous, and almost certainly the first example of an ecological study in modern epidemiology is the "Ghost Map" developed by Dr John Snow in 1854 in response to a major cholera outbreak in London. The "Ghost map" was a geographical grid that showed the cases of cholera and their proximity to a public well believed to be the source of cholera (Hempel 2013).

In Ontario, Canada, Strauss et al. (2001) conducted a prospective ecological study of 235 rural households served by private wells. Data was collected on self-reported AGI and well water samples were measured for faecal indicator organisms. No relationship was established between self-reported AGI and wells containing faecal indicator organisms. Conversely, in a similar study from Ontario, Canada, E. coli present in well water was significantly associated with gastrointestinal illness, with this relationship modified by the distance of the septic tank to the well (Raina et al. 1999). Wells located $>20 \mathrm{~m}$ from a septic tank were associated with greater odds of contributing to gastrointestinal illness than those $<20 \mathrm{~m}$ from the septic tank (OR 2.16; 95\% CI 1.04, 4.42).

Uhlmann et al. (2009) employed geographic information systems (GIS) as part of an observational study which 
demonstrated a 5.2-fold increased risk of AGI among those served by private wells in British Columbia than those served by municipal groundwater supplies. Similarly, Dangendorf et al. (2002) have presented evidence of a significant association between disease incidence and the number of people served by groundwater in Germany. ÓhAiseadha et al. (2017) investigated the potential risk factors for 989 confirmed primary verotoxigenic $E$. coli (VTEC) infections in the Republic of Ireland during the period 2008-2013. Spatial geo-referencing and derivation were used to positively identify three predictors of VTEC notification, namely private well usage (OR 6.896, $p<0.001$ ), cattle density (OR 1.002, $p$ $<0.001$ ) and septic tank density (OR 0.978, $p=0.002$ ).

\section{Pathogens of concern in groundwater}

The following section provides an outline of the most significant enteric pathogens with respect to groundwater contamination and human illness, including what is known about their survival and movement in the subsurface. A summary of previous studies comprising data on enteric pathogens isolated from global groundwater supplies under both outbreak and non-outbreak conditions are presented in Table 4. While this summary is not exhaustive, it will assist in providing a broad context on what is currently known about enteric pathogen presence in groundwater supplies, in addition to highlighting any significant knowledge gaps. Knowledge around the types and concentrations of pathogens along with their persistence in groundwater supplies is needed to inform risk assessment models. In the absence of epidemiological data, quantitative microbial risk assessment (QMRA) can be used to estimate and to quantify risks of AGI attributable to specific pathogens found in groundwater supplies. Examples of QMRA models employed for groundwater are presented in see section 'Quantitative microbial risk assessment'.

\section{Bacteria}

Bacteria are the microbial group of most importance in terms of both frequency of isolation in drinking water and the number of reported waterborne disease outbreaks (Gray 1997). Although numerous bacterial species may and have been found to contaminate aquifers, some are more prevalent than others. As previously outlined, the most widespread waterborne disease throughout history has been cholera, with the first major epidemic in Europe killing over one million people from 1830-1832 (Wyn-Jones 2000). However, many of these traditional waterborne diseases (i.e. cholera and typhoid) have largely disappeared from Europe and North America, due to advances in microbiology, epidemiology and medicine, as evidenced by Craun et al. (2006), who report that during the period 1920-1940, 70\% of waterborne disease outbreaks in the United States presented as typhoid fever, compared to 22 and $11 \%$ of outbreaks during the periods 1941-1960 and 1961-1970, respectively. Although typhoid fever has not been a major causative agent of waterborne infection since then, many of the "classical" waterborne infections are still of major importance in poorer developing countries. The primary bacterial pathogens associated with groundwater supplies are now outlined.

\section{Salmonella spp.}

Salmonella are bacterial pathogens present in both human and animal faeces and are capable of causing a range of enteric infections depending upon the serotype involved, including gastroenteritis, salmonellosis, typhoid fever and paratyphoid fever (Gill et al. 2003). Salmonella is primarily transmitted through improper handling and cooking of food; however, it can also be found and transmitted via water. The most common symptoms of Salmonella gastroenteritis include diarrhoea, fever, and abdominal cramps, with illness typically lasting 4-7 days (Bemrah et al. 2003; CDC 2016a). Boehm et al. (2012) report that Salmonella can persist in dark freshwater microcosms for at least 53 days with little to no decay. One documented waterborne outbreak of Salmonella associated with a groundwater supply occurred in Gideon, Missouri in 1993, with the outbreak affecting approximately 650 people, 15 of whom were hospitalized, with 7 associated deaths. In this case, the outbreak was associated with community wells, all of which tested positive for Salmonella typhimurium (Angulo et al. 1997).

\section{Pathogenic E. coli}

E. coli are bacteria, ubiquitously found in the lower intestine of warm blooded animals including humans with a number of strains capable of causing infection (Haas et al. 1999). These pathogenic strains are characterized into five main virotypes (Todar 2007), of which the enterohaemorrhagic (EHEC) serotype $\mathrm{O} 157$ is perhaps the best known.

Virulent strains of $E$. coli can cause gastroenteritis, urinary tract infections, and neo-natal meningitis, with gastroenteritis being the most prevalent form of illness associated with waterborne serotypes. Survival of $E$. coli is similar throughout the serotypes, and they are capable of multiplying in warm nutrient-rich conditions (e.g. septic tank effluents; Gray 2004). Approximately 100 organisms are required to cause infection, with gastroenteric symptoms comprising profuse watery diarrhoea, nausea and dehydration. The majority of waterborne $E$. coli outbreaks detailed in the literature focus on the verotoxin-producing, EHEC strain O157.

Verotoxigenic (or verotoxin-producing) E. coli (VTEC) including serotype O157:H7 is associated with a wide range of severity of illnesses from mild diarrhoea to haemorrhagic 
colitis and haemolytic uraemic syndrome (HUS), which causes the intravascular lysis of red blood cells (Garvey et al. 2010). In severe cases, HUS can result in irreversible renal failure, requiring haemodialysis, and in a minority of cases, may prove fatal (Coffey et al. 2007). HUS associated with VTEC is the most common cause of renal failure in children (Garvey et al. 2010). Animals, and in particular cattle and other ruminants, are a primary environmental reservoir (Szewzyk et al. 2000; Rosen 2000; Garvey and McKeown 2008), resulting in this virulent $E$. coli strain's association with rural areas' private groundwater sources. Drinking troughs and moist mixed cattle rations have been cited as sources of VTEC on farms (Hancock et al. 2001).

Perhaps the most notable outbreak of groundwater-related E. coli $\mathrm{O} 157: \mathrm{H} 7$ infection was that of Walkerton, Ontario, Canada in 2000 where seven people died and over 2,000 became ill as a result of exposure to E. coli $\mathrm{O} 157: \mathrm{H} 7$ and Campylobacter jejuni found in the community groundwater supply (Holme 2003). In 1999, a serious outbreak of E. coli affected the state of New York with more than 1,000 people affected and 2 deaths. It was reported that a total of 122 cases of $E$. coli $\mathrm{O} 157: \mathrm{H} 7$ were confirmed, 65 people were admitted to hospital and 11 children developed HUS. Two people (a 3year old girl and a 79-year old man) died (Charatan 1999; Hrudey and Hrudey 2004). The source of the infection was a contaminated well at the Washington County Fair, with runoff from cattle manure after torrential rain thought to be responsible (Charatan 1999). A study by Schets et al. (2005) reported E. coli $\mathrm{O} 157: \mathrm{H} 7$ presence in $2.7 \%$ of private groundwater supplies in the Netherlands, with pulsed field gel electrophoresis (PFGE) analysis suggesting that cattle were the most probable source.

\section{Shigella spp.}

Shigella are a genus of bacteria closely related to E. coli and Salmonella (CDC 2016a), although they have a lower environmental survival rate than both of these organisms (Bitton 2005). The disease is characterized by a short period of watery diarrhoea with intestinal cramps and general malaise, followed by permanent emission of bloody stools, known as haematochizia (DuPont 2010; CDC 2016a). Shigella is characterized by an extremely low threshold dose and therefore has a high potential for person-to-person (secondary) propagation (Wikswo and Hall 2012). Alamanos et al. (2000) reported a waterborne outbreak of shigellosis which occurred in a community of 2,213 persons in north-western Greece during October 1999. In all, 288 inhabitants of the village of Eleoussa, suffered from gastroenteritis, with the peak of the epidemic occurring during the first 3 days. The highest risk of developing gastroenteritis was observed in the 0-14-year age group (41.4\%) and decreased significantly with age $(p<0 \cdot 01)$. Patients over 65 years were more frequently hospitalized than those in other age groups $(p<$
$0 \cdot 05)$. Shigella sonnei was isolated from both water and human faecal samples (Alamanos et al. 2000). Environmental conditions suggested that infection was caused via contaminated groundwater sources. Shigella has been linked to 20 groundwater outbreaks in the United States between 1971-2008 (Wallender et al. 2014). Additionally, it has been isolated from groundwater supplies in Nigeria and South Korea (Giwa et al. 2015; Joung et al. 2013).

\section{Campylobacter spp.}

Campylobacter are a bacterial genus with at least 17 known species, of which Campylobacter jejuni, Campylobacter coli, Campylobacter fetus and Campylobacter rectus species are the most important from a human health perspective (Altekruse et al. 1999). Campylobacter jejuni and Campylobacter coli are two of the most common causes of bacterial gastroenteritis worldwide, with illness characterized by severe diarrhoea, cramping, fever, and abdominal pain (StPierre et al. 2009; Pagaya et al. 2015). Symptoms may subside after a number of days or persist for weeks and can become more severe in immunocompromised persons. Rarely, more severe symptoms may develop such as reactive arthritis, Reiter's syndrome, or HUS, with approximately one in every 1,000 cases leading to a severe neurological disorder called Guillain-Barré Syndrome (CDC 2016b).

Campylobacter species are found in the faeces of humans, livestock and a number of wildlife species, and are therefore common in the environment (Szewzyk et al. 2000; Whiley et al. 2013). A number of Campylobacter outbreaks have been positively associated with waterborne transmission routes, particularly in Scandinavian countries including Denmark (Engberg et al. 1998), Finland (Hänninen et al. 2003), Norway (Jakopanec et al. 2008), and Sweden (Andersson et al. 1997). Waterborne exposures are often associated with faecal contamination of the water source from agricultural waste run-off, bird droppings or sewage outflow (Hänninen et al. 2003). Survival in water can be from several weeks up to 3 months provided the temperature is low (Altekruse et al. 1999; Nicholson et al. 2005). Chlorination is a highly effective barrier against Campylobacter species in water and therefore, where waterborne illness occurs, it is largely associated with untreated private water supplies (Coffey et al. 2007). One waterborne Campylobacter jejuni outbreak in Denmark in 1995 resulted in an estimated 2,400 symptomatic infections, with contamination of the water supply positively traced to contamination of groundwater due to a break in a sewage pipe (Engberg et al. 1998). A recent QMRA from New Zealand predicted that consumers receiving their drinking water from shallow groundwater in an intensive dairy region (Waikakahi catchment, Canterbury) had an estimated 60-75\% chance of contracting campylobacteriosis during the irrigation season (Hynds et al. 2014b; Murphy et al. 2016a). 


\section{Vibrio cholerae}

$V$. cholera is a bacterial pathogen, and is the causative organism for cholera. Cholera is now rare in developed countries; however, it remains endemic in developing regions including Africa and Southeast Asia (Lutz et al. 2013; CDC 2016c). Of the approximately 221,000 cases reported globally in 2009 , 98\% were associated with African countries (WHO 2010). According to Rebaudet et al. (2013), cholera represents a "prototypical waterborne and environmental disease". Cholera is a diarrhoeal disease with severity ranging from asymptomatic infection to severe diarrhea and vomiting resulting in death. As part of the current scoping review, the presence of cholera in groundwater supplies under outbreak and non-outbreak conditions were retrieved from three articles (Akoachere et al. 2013; Giwa et al. 2015; Koch 2013). In the city of Douala, Cameroon, cholera outbreaks are common, particularly in New Bell District where the water table is high and inhabitants rely on shallow wells for drinking and household uses (Akoachere et al. 2013). These shallow supplies are extremely vulnerable to microbial contamination. Densely populated urban environments such as those found in major cities in Nigeria experience similar conditions, whereby people rely on groundwater that can be heavily contaminated with faecal waste due to a lack of adequate sanitation (Giwa et al. 2015). These are ideal conditions for cholera and other pathogens to enter the water supply.

Interestingly, while three-quarters of all cholera cases in Africa between 2009-2011 occurred in inland areas, V. cholera has rarely been isolated from water supplies in these regions (Rebaudet et al. 2013). Moreover, the natural habitat of $V$. cholera is typically brackish or saline water (Lutz et al. 2013). Sorensen et al. (2015) recently found that V. cholera was persistent in $41 \%$ of groundwater samples analyzed from Kabwe, Zambia, with the bacteria exhibiting an ability to enter a viable but non-culturable (VBNC) state in order to survive in unfavorable environments.

\section{Viruses}

Viruses are pathogens of particular concern with respect to groundwater as they are shed in large quantities in the environment, while their size results in lower attenuation and relatively rapid transport to and within aquifers (Macler and Merkle 2000; Bradbury et al. 2013). Culturable enteric viruses have been found in numerous groundwater supplies across the US (Abbaszadegan et al. 2003; Borchardt et al. 2003, 2004, 2007, 2012; Bradbury et al. 2013; Lambertini et al. 2012). A recent systematic review of groundwater systems in North America found that $88.5 \%$ of US studies included for metaanalysis reported the presence of enteric viruses in analyzed groundwater samples, with viruses more frequently identified than either bacterial or protozoan pathogens (Hynds et al. 2014b). There are over 140 distinct known types of human pathogenic virus, with those of most concern being the enteric viruses which cause gastrointestinal illnesses including enteroviruses, rotaviruses, astroviruses, calciviruses, hepatitis A virus and norovirus (Gray 2004).

\section{Norovirus}

Norovirus (previously called Norwalk-like viruses and more commonly known as the "winter vomiting bug") is an RNA virus (taxonomic family Caliciviridae), identified as the leading cause $(\approx 90 \%)$ of epidemic non-bacterial gastroenteric outbreaks around the world (Hall et al. 2013). In the United States alone, noroviruses have been estimated to cause between 1921 million illnesses per year, including 57-800 deaths, 56,000-71,000 hospitalizations, 400,000 emergency department visits and 1.7-1.9 million out-patient visits (Hall et al. 2013). The primary transmission routes are faecally contaminated food or water, and person-to-person contact (Lee 2011). Infected individuals are associated with shedding rates of $10^{5}$ $10^{9}$ particles per gram in feces; therefore, leaking septic and sewage systems are significant sources of groundwater contamination (Lopman et al. 2012; Bradbury et al. 2013; Hynds et al. 2014b). Additionally, norovirus is excreted by adults for up to 3 weeks, and up to 47 days in young children (Murata et al. 2007). It is also capable of surviving and remaining infectious in water for up to 2 months (Lopman et al. 2012). Norovirus outbreaks are primarily associated with closedcommunities such as hospitals, retirement homes, cruise ships, etc. (Gallimore et al. 2005; Coffey et al. 2007). Typically, acute gastroenteritis develops $24-48 \mathrm{~h}$ after exposure, lasting for 24-60 h. The disease is usually self-limiting, and characterized by nausea, vomiting, diarrhoea, and abdominal pain. General lethargy, weakness, muscle aches, headache, and lowgrade fever may also occur (Zheng et al. 2010).

Consumers drinking water from a contaminated well in central Wyoming, which was suspected of having been contaminated by sewage, were found to be 4.5 times more likely to present with gastroenteric symptoms than those who had not consumed from the well, with norovirus confirmed as the causative infectious organism (Parshionikar et al. 2003). Manuala et al. (2005) previously found that a high proportion of norovirus contamination events occurring in Finland are attributable to groundwater systems, with almost $50 \%$ of groundwater outbreaks associated with private water wells. Reporting on a recent norovirus outbreak associated with a private well in a dolomite aquifer in northeast Wisconsin, (Borchardt et al. 2011b) found that 229 patrons of a new restaurant were affected during the incident, which was positively confirmed as being due to ingress of septic tank effluent into a nearby private well - both the septic tank and well conformed to state regulations in this case. Both Borchardt et al. (2012) and Bradbury et al. (2013) have found enteric 
viruses including norovirus in deep confined aquifers assumed to be free of pathogens; bedrock fractures and improperly sealed well casings both represent pathways for viral intrusion to and within these aquifers. In the current review, norovirus was the pathogen most frequently responsible for groundwater outbreaks reported within the academic literature (Table 2).

\section{Adenovirus and enterovirus}

Adenoviruses and enteroviruses are non-enveloped DNA viruses, approximately one third of which are capable of causing human infection. Adenoviruses in particular are unusually stable in the presence of chemical and physical agents and extreme $\mathrm{pH}$ conditions, thus permitting prolonged survival outside a host (Mena and Gerba 2009). A recent study has found that adenovirus remained relatively stable in seeded groundwater at $10{ }^{\circ} \mathrm{C}$ for at least 160 days and up to 301 days (Rigotto et al. 2011). This is a concern, as $10^{\circ} \mathrm{C}$ is comparable with annual mean groundwater temperatures in many temperate regions. Studies have shown that adenoviruses survive longer in water than enteroviruses and hepatitis A virus, likely due to their double-stranded DNA (Ogorzaly et al. 2010; Carratalà et al. 2013). Both adenovirus and enterovirus may be transmitted via the faecal-oral route, diarrhea with oral transmission typically causing relatively mild infection; the typical incubation period for gastroenteritis is $3-10$ days (Mena and Gerba 2009).

Bradbury et al. (2013) found that $47 \%$ (67/147) of samples collected over a 2-year period from six deep (220-300 m) community groundwater wells contained enteroviruses and/ or adenoviruses. Based on results of the present review, both enteroviruses $(n=16)$ and adenoviruses $(n=6)$ have been identified in groundwater supplies during non-outbreak conditions (Table 4). Mena and Gerba (2009) report that adenovirus is responsible for more recreational waterborne outbreaks than any other enteric virus. To date, just two outbreaks in Finland and Albania, and one outbreak in Taiwan have been linked to groundwater for adenovirus and enterovirus, respectively (Table 2); nevertheless, given that both organisms manifest via respiratory symptoms, the authors suspect that their link to waterborne exposures may be significantly under-reported. The waterborne adenovirus outbreak reported by Kukkula et al. (1997) is of particular interest, as ingress of contaminated river water at a wellhead was found to be the source of the outbreak. In all, some 1,500-3,000 people, accounting for $25-50 \%$ of the affected Finnish community, were affected. Laboratory findings confirmed adenovirus, norovirus, and group $\mathrm{A}$ and $\mathrm{C}$ rotaviruses as causative agents.

\section{Rotavirus}

Rotavirus is a genus of double-stranded RNA virus and the most common cause of severe diarrhoea among infants and young children worldwide (Glass 2006). Globally, it is estimated to be responsible for an estimated 610,000 child mortalities per year, accounting for approximately $5 \%$ of all deaths in those $<5$ years (Glass 2006). Rotavirus may be found in water sources, including private wells, which have been contaminated with faeces from infected humans, with sewage overflows or inoperative sewage systems primarily responsible for contamination (Parashar et al. 2006). The virus is highly resistant in the natural environment and can be present in large amounts in wastewater (Macler and Merkle 2000). Previous studies (Abbaszadegan et al. 2003; AzadpourKeeley and Ward 2005) have found that enteric viruses may survive for many weeks in groundwater environments, with Sobsey et al. (1995) reporting that there was little, if any, viral inactivation in samples from a deep well in North Carolina over an 8-week period. More recently, Espinosa et al. (2008) demonstrated that rotavirus can survive and remain virulent for $>210$ days in groundwater. In addition, they demonstrated that rotaviral infectivity is tolerant to residual chlorine concentrations of between $0.1-1.5 \mathrm{mg} / \mathrm{L}$, higher than those recommended by the World Health Organization (WHO) for water used for human consumption. Symptoms of rotaviral infection in humans include vomiting and watery diarrhoea (Parashar et al. 2006). Infections often occur as winter epidemics with a high level of secondary (person-to-person) transmission, which is mainly of faecal-oral origin. As few as 10 viral particles are sufficient to cause symptomatic illness (CDC 2016c).

Rotavirus has been isolated from groundwater supplies in North America, South Korea and Slovenia (Table 4) and has been responsible for groundwater related outbreaks in France and Finland (Table 2). Both groundwater-related outbreaks were characterized by the presence of multiple causative pathogens - for example, a large waterborne outbreak occurred in France during August 2000. Local residents that reported having drunk tap water were characterized by a three-fold increased risk for illness, with the risk increasing in concurrence with consumed volume. Campylobacter coli, group A rotavirus and norovirus were identified in patient stool samples, with a community groundwater source probably contaminated by agricultural run-off, and a chlorination failure identified as the likely causes of the outbreak (Gallay et al. 2006).

\section{Hepatitis A}

Hepatitis A virus (HAV) is a waterborne virus responsible for $50 \%$ of global hepatitis cases (Bosch et al. 2008). Hepatitis A virus (HAV) is a viral pathogen capable of causing both acute and chronic illness, and most frequently associated with consumption of contaminated food or water; while rarely responsible for human mortality, infection is capable of significantly incapacitating patients for up to several months (Bosch et al. 2008). 
The disease is frequently asymptomatic, with symptomatic infection usually appearing 2-6 weeks subsequent to exposure and presenting as fever, fatigue, loss of appetite, vomiting, and nausea (CDC 2015). The virus has been responsible for a significant number of virus-related groundwater outbreaks globally (Table 2) and has been recovered from groundwater supplies in North America (Table 4). Between 1971 and 2008, 21 outbreaks $(8.5 \%)$ in the US with known etiology were attributed to hepatitis $\mathrm{A}$ in untreated groundwater supplies (Wallender et al. 2014). It was the most common pathogen linked to outbreaks in untreated groundwater supplies during this time period in the US, followed by Shigella $(20,8.1 \%)$ and G. intestinalis (14, 5.7\%; Wallender et al. 2014).

\section{Protozoa}

Protozoa (from the Greek words proton, meaning "first", and zoa, meaning "animals") are a subkingdom of microorganisms. Most are free-living, some of which can cause disease, whereas others are obligate parasites (i.e. cannot reproduce outside a host; Haas et al. 1999). They form structures called cysts, oocysts or spores (depending on the life cycle of the organism), which are resistant to adverse conditions such as high temperatures and disinfection (Karanis et al. 2007). Pathogenic (i.e. infectious) protozoa are primarily excreted in the faeces or urine of infected human or animal host, and transmitted during the infectious (oo) cyst stage via the faecal-oral route (Haas et al. 1999). This section focuses on the two most important protozoa found in groundwater supplies that can cause AGI: G. lamblia and Cryptosporidium spp.

\section{Giardia spp.}

Giardia spp. is a protozoan parasite, with G. lamblia being the most commonly encountered species, particularly in water supplies (Hunter and Thompson 2005)., et al (sis is the most common protozoan infection of the human intestine worldwide (Haas et al. 1999), with prevalence ranging from 2-5\% in the developed world to $20-30 \%$ in the developing world (Marshall et al. 1997). Symptomatic illness is characterized by acute diarrhoea, foul-smelling stools, upper or mid-epigastric cramps, bloating and flatulence, with patients usually expressing feelings of malaise, nausea and sulfuric belching. The prolonged duration of diarrhoea, frequently continuing for 2-4 weeks, is a typical feature of giardiasis (Haas et al. 1999; Ashbolt 2004).

G. lamblia is found in a wide range of animals (Gray 2004), with cysts capable of surviving for long periods in groundwater (and surface water) environments, particularly at cold temperatures during the winter months $\left(2-3\right.$ months at $<10^{\circ} \mathrm{C}$; up to 1 month at $21^{\circ} \mathrm{C}$; LeChevallier et al. 1991; Coffey et al. 2007). Furthermore, when in its cyst form, it comprises a protective wall facilitating chlorine resistance.
During the period 1980-1985, there were 502 outbreaks of waterborne disease in the USA, with Giardia positively confirmed as the causative organism in $52 \%$ of these cases. One large outbreak occurred at a Colorado ski resort, when sewage contamination of a groundwater supply resulted in 123 people contracting symptomatic infection. During the period 1995 2004 , Giardia has been identified as the primary causative agent in $13 \%$ of 108 reported gastroenteric outbreaks associated with drinking water in the US (Yoder and Beach 2007). It should be noted that the proportion of these outbreaks directly attributable to contaminated groundwater could not be established. In the present review, Giardia was found to have been responsible for 16 groundwater related outbreaks worldwide (Table 2), and has been isolated from groundwater supplies in North America (independently of a confirmed human health impacts; Table 4).

\section{Cryptosporidium spp.}

Cryptosporidium spp. are protozoan parasites, with 21 currently recognized species of which two are particularly important in the context of human infection: Cryptosporidium parvum and Cryptosporidium hominus. Cryptosporidium parvum is the species primarily responsible for clinical illness in humans and animals (Fayer et al. 2000; Hrudey and Hrudey 2004). Cryptosporidiosis is now acknowledged as being a significant gastrointestinal disease in infants, young children and immunecompromised individuals (Chen et al. 2002; Cohen et al. 2006). The incubation period after ingestion of viable oocysts is 528 days with a mean of 7.2 days (Marshall et al. 1997; Haas et al. 1999) with symptoms lasting for up to 2 weeks. Clinical symptoms include an influenza-like illness, diarrhoea (characteristically cholera like), malaise, abdominal pain, anorexia, nausea, flatulence, mal-absorption, vomiting, mild fever and weight loss (Smith and Rose 1990; Gray 2004), with infection typically nonfatal and self-limiting in healthy adult hosts. However, the severity and duration of the disease is significantly higher among immunocompromised individuals (Gatei et al. 2006). Low-level exposure to oocysts (1-10) can initiate infection (Gray 2004), with studies indicating that a single oocyst may be adequate to cause infection (Boak and Packman 2001).

Cryptosporidium oocysts are capable of survival outside the intestine for considerable periods of time (Marshall et al. 1997; Fayer et al. 2000). A study by Robertson and Gjerde (2006) found that Cryptosporidium oocysts with viable morphology were detected after approximately 20 weeks during winter in an aquatic environment in Norway. However, as stated by Reynolds et al. (2008), the interaction between $\mathrm{pH}$, temperature and exposure time may have adverse effects on the survival of $C$. parvum oocysts in water and soils, and therefore an exact environmental survival rate is difficult to ascertain. 
Cryptosporidium are smaller in size than Giardia, and as a result have been more frequently isolated in groundwater supplies due to their ability to be more readily transported in the subsurface environment. Additionally, Cryptosporidium oocysts are more resistant to low temperatures and are therefore expected to survive longer than Giardia in groundwater environments (Carmena 2010). While Cryptosporidium has been more frequently found in groundwater supplies than Giardia, it has been linked to fewer groundwater-related outbreaks (Table 3). In a study by LeChevallier et al. (1991), Cryptosporidium was found more frequently than Giardia in surface waters, thus suggesting that the pathogen may be more prevalent in the environment. Although, Cryptosporidium was found more frequently in groundwaters cited in the present review, Zmirou-Navier et al. (2006) report that the probability of disease when infected by Cryptosporidium is around $70 \%$, whereas for Giardia it can be as high as $91 \%$, thus perhaps explaining why Cryptosporidium has not caused as many outbreaks in groundwater. Rose (1997), provides ranges for the occurrence of Cryptosporidium parvum oocysts in a range of media including raw sewage, filtered treated wastewater, surface waters and groundwaters, with a range of 0.004-0.922 oocysts per liter provided for groundwater samples, suggesting a background level of oocysts existing in groundwater bodies have the potential for human infection.

The low associated human threshold dose, coupled with high environmental resistance to environmental factors including disinfection by chlorination, has led to a number of large cryptosporidiosis outbreaks associated with contaminated drinking water throughout the world. Smith and Rose (1998) report that during the 10-year period 1988-1998, Cryptosporidium was the causative organisms in at least 19 waterborne outbreaks of cryptosporidiosis in the US (surface water and groundwater), affecting over 425,000 individuals. Three of these outbreaks were associated with contaminated wells and one with a suspected spring (Smith and Grimason 2003). Willocks et al. (1998) report on 345 confirmed cases of cryptosporidiosis in North Thames during spring 1997. A case control study, in addition to oocyst detection rates and descriptive epidemiology associated with the outbreak, indicated that the outbreak was associated with drinking unboiled tap water that originated from a deep chalk borehole. Garvey and McKeown (2005) report that a significant decrease in cryptosporidiosis cases in northwest England during the period 1997-2000, was likely attributable to developments in public water supplies, which would suggest that some burden of illness was associated with private water supplies. Hunter et al. (2011) have shown that the predicted risk of cryptosporidiosis (and giardiasis) among users of very small private supplies in England and France are substantially greater than for public water supplies and well above the tolerable risk threshold.

\section{Quantitative microbial risk assessment}

Quantitative microbial risk assessment (QMRA) represents a methodology that can be used to understand and estimate the risk of infection or illness associated with (individual or population) exposure to a specific pathogen (Haas et al. 1999). QMRA findings may be used to develop and undertake improved risk management and communication strategies (Vose 2000). As set out by Lammerding and Fazil (2000), the QMRA process comprises four steps, namely hazard identification, hazard characterization, exposure assessment, and risk characterization. The hazard (waterborne pathogen) is characterized by the likelihood of exposure (amount of water consumed), the infectivity and attack rate associated with the pathogen (the amount of infectious pathogen required to cause infection or illness). The methodology is pathogen-specific, and therefore in order to assess the risk of multiple pathogens, QMRAs need to be performed for each individual pathogen of concern (Teunis et al. 1997; Macler and Merkle 2000; Howard et al. 2003). Previous QMRAs of enteric infection attributable to consumption from groundwater sources have been undertaken for Cryptosporidium spp. (Cummins et al. 2010; Razzolini et al. 2016), E. coli O157 (Haas et al. 2000; Hynds et al. 2014a), Giardia spp. (Razzolini et al. 2016), and rotavirus (Rutjes et al. 2009), in addition to a recently published national-scale QMRA of multiple groundwater pathogens (Murphy et al. 2016b).

\section{Waterborne disease burden estimates}

The authors have identified six studies within the published literature attempting to quantify the burden of waterborne enteric disease attributed to groundwater supplies at a national level (Colford et al. 2006b; Macler and Merkle 2000; Messner et al. 2006; Reynolds et al. 2008; Murphy et al. 2016a, b). Three of these studies endeavored to provide estimates of disease burden among the population served by community water systems (CWS) in the United States (Colford et al. 2006b; Messner et al. 2006; Reynolds et al. 2008). Two of these studies included public and community systems served by groundwater but did not include private wells. Colford et al. (2006b) approximated the occurrence of 1.33-3.88 million illnesses per year attributable to community groundwater supplies, while Messner et al. (2006) estimated approximately 5.4 million cases of AGI annually. The third study considered both community and non-community groundwater supplies in the US and used QMRA to estimate the risk of viral infections from groundwater supplies (Reynolds et al. 2008). In this study, they estimated that 5.4 million and 1.1 million cases of symptomatic viral infections may be attributable to community and non-community groundwater supplies annually in the US, respectively. Prior to these estimates, Macler and 
Merkle (2000) provided a range of 890,000 to 5.9 million cases per year as a result of contaminated groundwater in the US.

More recently, Murphy et al. (2016a) have provided estimates of the AGI burden attributable to consumption of contaminated groundwater from private wells and small systems (serving less than 1,000 people) in Canada via a QMRA approach. Five key waterborne pathogens were selected, namely Cryptosporidium, Giardia, norovirus, Campylobacter, and E. coli O157. Findings indicate the incidence of AGI associated with consumption of contaminated groundwater from untreated private wells and chlorinated small systems (most common form of groundwater treatment in North America) to be 0.027 cases per person-year and 0.016 cases per personyear, respectively. Resulting estimates are markedly lower than those produced in the United States; a crude application of the generated Canadian incidence rates to the current global groundwater reliant population ( 2.2 billion), produces a global range of 35.2-59.4 million cases of illness per year.

\section{Discussion}

\section{Overall findings}

In this review, it was shown that untreated groundwater is a major source of enteric disease globally. The review identified 649 published groundwater outbreaks globally between 1948-2013 (Table 1). These outbreaks only represent the tip of the iceberg in terms of the number of illnesses attributable to groundwater, since AGI can be difficult to track due to its sporadic nature and due to under-reporting and under-diagnosis. Several epidemiological studies showed that there was an increased risk of AGI associated with the consumption of untreated private or municipal well water. Using results from a multi-pathogen QMRA conducted in Canada, the authors crudely estimate that between 35.2-59.4 million cases of AGI per year globally could be attributable to the consumption of untreated groundwater. The review identified 17 pathogens as being responsible for groundwater related outbreaks of which the top five pathogens were: norovirus, Campylobacter, Shigella, Hepatitis A and Giardia (Table 2). The main causes for pathogen intrusion into groundwater during outbreak and non-outbreak conditions included: septic system/ municipal sewage, heavy rainfall, well construction, geology, inadequate treatment, surface-water intrusion and agricultural activities (Table 3 ).

\section{Study limitations}

It is important to note that the present review did not utilize a formalized "systematic" approach, and is instead considered a scoping review. Typically, scoping reviews focus on comprehensive coverage, as opposed to realizing a specified standard of evidence (McColl et al. 2009), and are thus typified by a broad focus, rather than an exhaustive review (Gentles et al. 2010; Pham et al. 2014). Accordingly, the current study is associated with a number of inherent limitations, as follows: (1) due to database selection, some relevant studies may not have been identified, (2) only published peerreviewed academic journal papers were considered for inclusion, thus evidence from white papers, national databases, academic theses, and gray literature were not sought or employed, (3) no quality assessment and/or critical appraisal of included/excluded literature was undertaken, thus gaps in the published literature associated with low research quality were not identified, and (4) some level of publication bias will be present, i.e. study outcome(s) may have influenced the decision to publish (e.g. unconfirmed pathogen etiology, unconfirmed pathogen source, unconfirmed illness, etc.). In the current review, the authors consider it likely that publication bias due to insufficient or absent infrastructure are likely to create an imbalance between the availability of literature from developed and developing regions. Due to these stated limitations, study findings, while indicative, should be employed with caution.

\section{Future research needs}

Over the past 50 years, significant progress has been made in improving our understanding of the extent and potential consequences of groundwater contamination by enteric pathogens. Research has advanced on several fronts including: groundwater sampling methods, pathogen detection methods such as qPCR and other molecular approaches, pathogen transport in the subsurface as related to hydrogeological concepts and colloid filtration theory, pathogen survival in groundwater, the relationship between faecal indicator organisms and pathogens, the role of environmental factors such as temperature and precipitation, and finally, early estimates on the burden of illness from consumption of pathogen contaminated groundwater. Nevertheless, both data and knowledge gaps remain, thus necessitating further research and collaboration between health professionals, microbiologist and hydrogeologists in this area. Key areas of research for more research include: (1) pathogen transport and persistence in groundwater supplies, (2) presence, detection and microbiological sampling methods, (3) epidemiological studies.

\section{Pathogen transport and persistence in groundwater supplies}

An advanced science should seek to develop the necessary tools and subsequent capability to predict an outcome of interest; however, unfortunately, accurate prediction of the susceptibility of an individual groundwater source to pathogenic contamination remains a challenge. Some of this difficulty 
likely stems from the natural variability associated with sources of enteric pathogens in the environment, stemming from the rise and fall of infections within the host population releasing these pathogens to the environment via faecal wastes. The remaining difficulty lies with the unique subsurface transport characteristics of pathogens and the conceptual leap needed to transfer our nanoscale particle-level understanding of pathogen attachment/detachment to transport at the macro-scale (Hunt and Johnson 2017, this issue). Empirical models to predict well susceptibility to pathogens have been developed (Schijven et al. 2010). An alternative approach is the use of advanced statistical models to identify the set of independent variables (i.e., risk factors) most highly associated with well vulnerability, for example, proximity to faecal source, well casing depth, depth to water, etc. (Howard et al. 2003; Hynds et al. 2012). Allen et al. (2017, this issue) explore this statistical approach in a univariate fashion with a small set of wells. While these models might be specific to hydrogeological setting, (e.g., fractured bedrock, alluvial), any tool with reasonable predictive value for "at-risk" groundwater supplies should be welcomed by regulators and others responsible for protecting public health. The paper by Bradford and Harvey (2017) in this issue provides suggestions for future research specific to pathogen transport in groundwater.

Understanding pathogen survival in groundwater is important for establishing safe setback distances between faecal sources (e.g., septic systems) and drinking water wells, and for evaluating groundwater exposures to pathogens and the consequent health risks. Many studies on pathogen survival in groundwater are conducted via laboratory microcosms or groundwater mesocosms. Such study designs likely do not adequately represent the direct and indirect effects on pathogen survival from attachment to aquifer sediments, predation from invertebrates and protozoa, bacterial pathogen growth from nutrient inputs into the aquifer, and the complex interactions among the aquifer's native microbial community. Thus, further studies are needed which seek to adequately account for the abiotic and biotic conditions found in natural groundwaters, as these will likely yield the most accurate measurements of microbial subsurface survival.

\section{Presence, detection and microbiological sampling methods}

Additionally, and perhaps more fundamentally, an improved understanding of the effects of sample volume and sampling frequency on the likelihood of falsenegative results for pathogens, or for that matter, faecal indicator organisms in groundwater, is required. At present, logistics, costs, and precedent are the typical determinants of many sampling design programs, and rarely is the false-negative rate considered. Optimal sample volumes and frequency of sampling for pathogens in groundwater are unknown. Avoiding false-positives may be of little consequence with regard to health risk, but this too requires additional research before the importance of standardized sampling can be dismissed.

While there are a number of studies on the occurrence of pathogens in groundwater, the data tend to be biased towards particular geographic regions and pathogen types - for example, in the USA, groundwater pathogen studies are overrepresented in the upper Midwest, whereas few studies have been conducted in the southeastern region. Studies have tended to focus on viruses in groundwater, but there is a dearth of data on groundwater contamination by bacterial pathogens such as Salmonella spp. Campylobacter spp., Listeria, and pathogenic E. coli. Interestingly, colloid filtration theory predicts bacterial pathogens are the optimal size for transport through the subsurface to groundwater (Hunt and Johnson 2017, this issue), and with additional studies more may be learned regarding the existence of predominate pathogens in groundwater bacteria.

\section{Epidemiological studies}

As reported in this review, there are too few human health studies to accurately evaluate the burden of illness from pathogen-contaminated groundwater, the kind of data needed to develop effective public health policies. Groundwater-borne disease outbreaks in the USA and Europe are frequently underreported, and measurement of sporadic illness from groundwater exposures, potentially representing a significant fraction of total illness, requires expensive and labor-intensive epidemiological studies. The burden of illness attributable to household private wells and non-disinfected groundwater-supplied public water systems, the relationship between groundwater pathogen levels and disease risk, and whether measurements of faecal indicator organisms in groundwater truly protect public health are all highly uncertain.

Lastly, and most importantly, there is an immediate need for hydrogeologists to contribute their expertise in efforts to minimize pathogen-contaminated groundwater and minimize the risk of groundwater-borne disease. Hydrogeologists possess an inherent understanding of the complex and unpredictable nature of groundwater contamination. In collaboration with microbiologists and epidemiologists, hydrogeologists have an opportunity to help achieve these global public health goals.

Acknowledgements The authors would like to thank the reviewers and the editors of Hydrogeology Journal for their valuable comments. 


\section{References}

Abbaszadegan M, LeChevallier MW, Gerba C (2003) Occurrence of viruses in US groundwaters. J Am Water Works Assoc 95(9):107120

Adam EA, Yoder JS, Gould LH, Hlavsa MC, Gargano JW (2016) Giardiasis outbreaks in the United States, 1971-2011. Epidemiol Infect 11:1-12

Akoachere J-FTK, Masalla TN, Njom HA (2013) Multi-drug resistant toxigenic Vibrio cholerae O1 is persistent in water sources in New Bell-Douala, Cameroon. BMC Infect Dis 13:366

Alamanos Y, Maipa V, Levidiotou S, Gessouli E (2000) A community waterborne outbreak of gastro-enteritis attributed to Shigella sonnei. Epidemiol Infect 125(3):499-503

Allen A, Borchardt M, Kieke B, Dunfield K, Parker B (2017) Virus occurrence in private and public wells in a fractured dolostone aquifer in Canada. Hydrogeol J. doi:10.1007/s10040-017-1557-5

Andersson Y, de Jong B, Studahl A (1997) Waterborne Campylobacter in Sweden: the cost of an outbreak. Water Sci Technol 35(11-12):1114

Angulo FJ, Tippen S, Sharp DJ, Payne BJ, Collier C, Hill JE, Barrett T, Clark RM, Geldreich EE, Donnell HD, Swerdlow D (1997) A community waterborne outbreak of salmonellosis and the effectiveness of a boil water order. Am J Public Health 87(4):580-584

Atherholt TB, Bousenberry RT, Carter GP, Korn LR, Louis JB, Serfes ME, Waller DA (2012) Coliform bacteria in New Jersey domestic wells: influence of geology, laboratory, and method. Ground Water 51(4):562-574

Atherholt TB, Korn LR, Louis JB, Procopio NA (2015) Repeat sampling and coliform bacteria detection rates in New Jersey domestic wells. Ground Water Monit Remidiat 35(2):70-80

Auld H, MacIver D, Klaassen J (2004) Heavy rainfall and waterborne disease outbreaks: the Walkerton example. J Toxic Environ Health A 67(20-22):1879-1887

Bacci F, Chapman DV (2011) Microbiological assessment of private drinking water supplies Co. Cork, Ireland. J Water Health 738-751

Balbus JM, Embrey MA (2002) Risk factors for waterborne enteric infections. Curr Opin Gastroenterol 18(1):46-50

Ball D (2000) The need for a national well standard and suggested content. Proceedings of the Portlaoise Seminar 'Groundwater and the Law: Directives, Standards \& Regulations'. International Association of Hydrogeologists (Irish Group)

Barwick RS, Levy DA, Craun GF, Beach MJ, Calderon RL (2000) Surveillance for waterborne-disease outbreaks: United States, 1997-1998. MMWR CDC Surveill Summ 49(4):1-21

Beer KD (2015) Surveillance for waterborne disease outbreaks associated with drinking water: United States, 2011-2012. Retrieved from http://www.cdc.gov/mmwr/preview/mmwrhtml/mm6431a2.htm. Accessed August 15, 2016

Bessong PO, Odiyo JO, Musekene JN, Tessema A (2009) Spatial distribution of diarrhoea and microbial quality of domestic water during an outbreak of diarrhoea in the Tshikuwi community in Venda, South Africa. J Health Popul Nutr 27(5):652-659

Bitton G (2005) Wastewater microbiology, 3rd edn. Wiley-Liss, Hoboken, p 746

Blackburn BG (2004) Surveillance for waterborne-disease outbreaks associated with drinking water: United States, 2001-2002. Retrieved from http://www.cdc.gov/mmwr/preview/mmwrhtml/ss5308a4. $\mathrm{htm}$. Accessed August 15, 2016

Boak RA, Packman MJ (2001) A methodology for the assessment of risk of Cryptosporidium contamination of groundwater. Q J Eng Geol Hydrogeol 34(2):187-194

Boehm AB, Soetjipto C, Wang D (2012) Solar inactivation of four Salmonella serovars in fresh and marine waters. J Water Health 10(4):504
Borchardt MA, Bertz PD, Spencer SK, Battigelli DA (2003) Incidence of enteric viruses in groundwater from household wells in Wisconsin. Appl Environ Microbiol 69(2):1172-1180

Borchardt MA, Haas NL, Hunt RJ (2004) Vulnerability of drinking-water wells in La Crosse, Wisconsin, to enteric-virus contamination from surface water contributions. Appl Environ Microbiol 70(10):59375946

Borchardt MA, Bradbury KR, Gotkowitz MB, Cherry JA, Parker BL (2007) Human enteric viruses in groundwater from a confined bedrock aquifer. Environ Sci Technol 41(18):6606-6612

Borchardt MA, Bradbury KR, Alexander EC, Kolberg RJ, Alexander SC, Archer JR, et al (2011a) Norovirus outbreak caused by a new septic system in a dolomite aquifer. Ground Water 49(1):85-97

Borchardt MA, Bradbury KR, Alexander EC, Kolberg RJ, Alexander SC, Archer JR, et al (2011b) Norovirus outbreak caused by a new septic system in a dolomite aquifer. Ground Water 49(1):85-97

Borchardt MA, Spencer SK, Kieke BA, Lambertini E, Loge FJ (2012) Viruses in nondisinfected drinking water from municipal wells and community incidence of acute gastrointestinal illness. Environ Health Perspect 120(9):1272-1279

Bosch A, Guix S, Sano D, Pintó RM (2008) New tools for the study and direct surveillance of viral pathogens in water. Curr Opin Biotechnol 19(3):295-301

Bradbury KR, Borchardt MA, Gotkowitz M, Spencer SK, Zhu J, Hunt RJ (2013) Source and transport of human enteric viruses in deep municipal water supply wells. Environ Sci Technol 47(9):4096-4103

Bradford SA, Harvey RW (2017) Future research needs involving pathogens in groundwater. Hydrogeol J. doi:10.1007/s10040-016-1501-

Bridgman SA, Robertson RM, Syed Q, Speed N, Andrews N, Hunter PR (1995) Outbreak of cryptosporidiosis associated with a disinfected groundwater supply. Epidemiol Infect 115(3):555-566

Brooks T, Osicki RA, Springthorpe VS, Sattar SA, Filion L, Abrial D, Riffard S (2004) Detection and identification of Legionella species from groundwaters. J Toxic Environ Health A 67(20-22):18451859

Carmena D (2010) Waterborne transmission of Cryptosporidium and Giardia: detection, surveillance and implications for public health. In: A Mendez-Vilas (ed) Current research, technology and educationtopics in applied microbiology andmicrobial biotechnology, vol 1. Formatex Research Center, Badajoz, Spain, pp 3-14

Carratalà $\mathrm{A}$, Rusiñol M, Rodriguez-Manzano J, Guerrero-Latorre L, Sommer R, Girones R (2013) Environmental effectors on the inactivation of human adenoviruses in water. Food Environ Virol 5(4): 203-214

Charrois JWA (2010) Private drinking water supplies: challenges for public health. CMAJ : Can Med Assoc J 182(10):1061-1064. doi: 10.1503/cmaj.090956

Casemore D (2006) Towards a US national estimate of the risk of endemic waterborne disease: sero-epidemiologic studies. J Water Health 04(Suppl 2): 121

CDC (2012) Principles of epidemiology in public health practice: an introduction to applied epidemiology and biostatistics, 3rd edn. Retrieved from http://www.cdc.gov/ophss/csels/dsepd/ss1978/ ss1978.pdf. Accessed August 15, 2016

CDC (2015) Hepatitis A. Retrieved from http://www.cdc.gov/hepatitis/ hav/index.htm. Accessed August 15, 2016

CDC (2016a) Salmonella. Retrieved from http://www.cdc.gov/ salmonella/. Accessed August 15, 2016

CDC (2016b) Campylobacter. Retrieved from http://www.cdc.gov/ foodsafety/diseases/campylobacter/index.html. Accessed August 15,2016

CDC (2016c) Cholera. Retrieved from http://www.cdc.gov/cholera/ index.html. Accessed August 15,2016 
Cheong S, Lee C, Song SW, Choi WC, Lee CH, Kim S-J (2009) Enteric viruses in raw vegetables and groundwater used for irrigation in South Korea. Appl Environ Microbiol 75(24):7745-7751

Cho HG, Lee SG, Kim WH, Lee JS, Park PH, Cheon DS, et al (2014) Acute gastroenteritis outbreaks associated with ground-waterborne norovirus in South Korea during 2008-2012. Epidemiol Infect 142(12):2604-2609

Close M, Dann R, Ball A, Savill M, Pirie R, Smith Z (2008) Microbial groundwater quality and its health implications for a border-strip irrigated dairy farm catchment, South Island, New Zealand. J Water Health 6(1):83

Coffey R, Cummins E, Cormican M, O’Flaherty V, Kelly S (2007) Microbial exposure assessment of waterborne pathogens. Hum Ecol Risk Assess 13:1313-1351

Colford JM, Roy S, Beach MJ, Hightower A, Shaw SE, Wade TJ (2006a) A review of household drinking water intervention trials and an approach to the estimation of endemic waterborne gastroenteritis in the United States. J Water Health 04(Suppl 2):71

Colford JM, Roy S, Beach MJ, Hightower A, Shaw SE, Wade TJ (2006b) A review of household drinking water intervention trials and an approach to the estimation of endemic waterborne gastroenteritis in the United States. J Water Health 04(Suppl 2):71

Craun GF (1992) Waterborne disease outbreaks in the United States of America: causes and prevention. World Health Stat Q 45:192-192

Craun GF, Calderon RL (2006) Workshop summary: estimating waterborne disease risks in the United States. J Water Health 04(Suppl 2): 241

Craun GF, Brunkard JM, Yoder JS, Roberts VA, Carpenter J, Wade T, et al (2010) Causes of outbreaks associated with drinking water in the United States from 1971 to 2006. Clinical Microbiol Rev 23(3): 507-528

Curriero FC, Patz JA, Rose JB, Lele S (2001) The association between extreme precipitation and waterborne disease outbreaks in the United States, 1948-1994. Am J Public Health 91(8):1194-1199

Dangendorf F, Herbst S, Reintjes R, Kistemann T (2002) Spatial patterns of diarrhoeal illnesses with regard to water supply structures: a GIS analysis. Int J Hygiene Environ Health 205(3):183-191

Darnault CJG, Garnier P, Kim YJ, Oveson KL, Steenhuis TS, Parlange JY, et al (2003) Preferential transport of Cryptosporidium parvum oocysts in variably saturated subsurface environments. Water Environ Res 75(2):113-120

Datta SS, Ramakrishnan R, Murhekar MV (2012) A rapidly-progressing outbreak of cholera in a shelter-home for mentally-retarded females, amta-II block, Howrah, West Bengal, India. J Health Popul Nutr 30(1):109-112

Denno DM, Keene WE, Hutter CM, Koepsell JK, Patnode M, FlodinHursh D, et aI (2009) Tri-county comprehensive assessment of risk factors for sporadic reportable bacterial enteric infection in children. J Infectious Dis 199(4):467-476

Divizia M, Gabrieli R, Donia D, Macaluso A, Bosch A, Guix S, et al (2004) Waterborne gastroenteritis outbreak in Albania. Water Sci Technol 50(1):57-61

DuPont HL, Mandell GM, Bennett JE, Dolin R (2010) Shigella Species (Bacillary Dysentery). In: Mandell, Douglas, and Bennett's principles and practice of infectious diseases, vol 1, 7th edn. Churchill Livingstone Elsevier, Philadelphia, pp 2905-2910

Espinosa AC, Mazari-Hiriart M, Espinosa R, Maruri-Avidal L, Mendez E, Arias CF (2008) Infectivity and genome persistence of rotavirus and astrovirus in groundwater and surface water. Water Res 42: $2618-2628$

Flanagan S, Johnston R, Zheng Y (2012) Arsenic in tube well water in Bangladesh: health and economic impacts and implications for arsenic mitigation. Bull World Health Organ 90(11):839-846

Fong T-T, Mansfield LS, Wilson DL, Schwab DJ, Molloy SL, Rose JB (2007) Massive microbiological groundwater contamination associated with a waterborne outbreak in Lake Erie, South Bass Island, Ohio. Environ Health Perspect 115(6):856-864

Fout GS, Martinson BC, Moyer MWN, Dahling DR (2003) A multiplex reverse transcription-PCR method for detection of human enteric viruses in groundwater. Appl Environ Microbiol 69(6):3158-3164

Fullerton KE, Ingram LA, Jones TF, Anderson BJ, McCarthy PV, Hurd S, et al (2007) Sporadic Campylobacter infection in infants: a population-based surveillance case-control study. Pediatric Infectious Dis J 26(1):19-24

Gallay A, De Valk H, Cournot M, Ladeuil B, Hemery C, Castor C, et al (2006) A large multi-pathogen waterborne community outbreak linked to faecal contamination of a groundwater system, France, 2000. Clinical Microbiol Infect 12(6):561-570

Garvey P, McKeown P (2008) Epidemiology of verotoxigenic E. coli in Ireland, 2006. Epi-Insight 9(2):2-3

Garvey P, Carroll A, Mc NE, McKeown P (2010) Epidemiology of verotoxigenic E. coli in Ireland, 2009. Epi-Insight 11(9):1-3

Gatei W, Wamae CN, Mbae C, Waruru A, Mulinge E, Waithera T, Gatika SM, Kamwati SK, Revathi G, Hart CA (2006) Cryptosporidiosis: prevalence, genotype analysis and symptoms associated with infections in children in Kenya. Am J Trop Med Hyg 75:78-82

Giammanco GM, Di Bartolo I, Purpari G, Costantino C, Rotolo V, Spoto $\mathrm{V}$, et al (2014) Investigation and control of a Norovirus outbreak of probable waterborne transmission through a municipal groundwater system. J Water Health 12(3):452-464

Gill CJ, Keene WE, Mohle-Boetani JC, Farrar JA, Waller PL, Hahn CG, Cieslak PR (2003) Alfalfa seed decontamination in a salmonella outbreak. Emerg Infect Dis 9:474-479

Giwa F, Giwa A, Aboh E (2015) Microbiological assessment of well waters in Samaru, Zaria, Kaduna, State, Nigeria. Ann Afr Med 14(1):32

Gorelick MH, McLellan SL, Wagner D, Klein J (2011) Water use and acute diarrhoeal illness in children in a United States metropolitan area. Epidemiol Infect 139(02):295-301

Guzman-Herrador B, Carlander A, Ethelberg S, de Blasio BF, Kuusi M, Lund V, et al (2015) Waterborne outbreaks in the Nordic countries, 1998 to 2012. Euro Surveill 20(24), 21160

Haas CN, Rose JB, Gerba CP (1999) Quantitative microbial risk assessment. John Wiley, New York

Haas CN, Thayer-Madabusi A, Rose JP, Gerba CP (2000) Development of a dose-response relationship for Escherichia coli O157:H7. Int J Food Microbiol 1748:153-159

Hall AJ, Lopman BA, Payne DC, Patel MM, Gastañaduy PA, Vinjé J, Parashar UD (2013) Norovirus disease in the United States. Emerg Infect Dis 19(8): 1198-1205

Hancock D, Besser T, Lejeune J, Davis M, Rice D (2001) The control of VTEC in the animal reservoir. Int J Food Microbiol 66(1-2):71-78

Hänninen ML, Haajanen H, Pummi T, Wermundsen K, Katila ML, Sarkkinen H, et al (2003) Detection and typing of Campylobacter jejuni and Campylobacter coli and analysis of indicator organisms in three waterborne outbreaks in Finland. Applied Environ Microbiol 69(3):1391-1396

Haznedaroglu BZ, Yates MV, Maduro MF, Walker SL (2012) Effects of residual antibiotics in groundwater on Salmonella typhimurium: changes in antibiotic resistance, in vivo and in vitro pathogenicity. J Environ Monit 14(1):41-47

Herwaldt BL, Craun GF, Stokes SL, Juranek DD (1991) Waterbornedisease outbreaks, 1989-1990. MMWR CDC Surveill Summ 40(3):1-21

Holme R (2003) Drinking water contamination in Walkerton, Ontario: positive resolutions from a tragic event. Health-Related Water Microb 47(3): 1-6

Howard G, Pedley S, Barrett M, Nalubega M, Johal K (2003) Risk factors contributing to microbiological contamination of shallow groundwater in Kampala, Uganda. Water Res 37(14):3421-3429 
Hrudey SE, Hrudey EJ (2004) Safe drinking water - lessons from recent outbreaks in affluent nations. IWA Publishing, London, p 514

Hunt JR, Johnson WP (2017) Pathogen transport in groundwater systems: contrasts with traditional solute transport. Hydrogeol J. doi:10.1007/ s10040-016-1502-z

Hunter PR, de Sylor MA, Risebro HL, Nichols GL, Kay D, Hartemann P (2011) Quantitative microbial risk assessment of cryptosporidiosis and giardiasis from very small private water supplies: quantitative microbial risk assessment of Cryptosporidiosis and Giardiasis. Risk Anal 31(2):228-236

Hynds PD, Misstear BD, Gill LW (2012) Development of a microbial contamination susceptibility model for private domestic groundwater sources. Water Resour Res 48(12)

Hynds PD, Misstear BD, Gill LW (2013) Unregulated private wells in the Republic of Ireland: Consumer awareness, source susceptibility and protective actions. J Environ Manag 127:278-288

Hynds PD, Gill LW, Misstear BD (2014a) A quantitative risk assessment of verotoxigenic E. coli (VTEC) in private groundwater sources in the Republic of Ireland. Human and ecological risk assessment: Int J 20(6):1446-1468

Hynds PD, Thomas MK, Pintar KDM (2014b) Contamination of groundwater systems in the US and Canada by enteric pathogens, 1990 2013: a review and pooled-analysis. PLoS One 9(5):e93301

Irish Environmental Protection Agency (2016) Protecting your private well. Retrieved from http://www.epa.ie/water/dw/hhinfo/ protprivwell/. Accessed August 15, 2016

Jakopanec I, Borgen K, Vold L, Lund H, Forseth T, Hannula R, Nygård K (2008) A large waterborne outbreak of campylobacteriosis in Norway: the need to focus on distribution system safety. BMC Infect Dis 8:128

Jean J-S, Guo H-R, Chen S-H, Liu C-C, Chang W-T, Yang Y-J, Huang M-C (2006) The association between rainfall rate and occurrence of an enterovirus epidemic due to a contaminated well. J Appl Microbiol 101(6):1224-1231

Job CA (2009) Groundwater economics. CRC Press, Taylor Francis Group, Boca Raton, FL, USA

Joung HK, Han SH, Park SJ, Jheong WH, Ahn TS, Lee JB, et al (2013) Nationwide surveillance for pathogenic microorganisms in groundwater near Carcass Burials constructed in South Korea in 2010. Int J Environ Res Public Health 10(12):7126-7143

Jung S, Hwang B-M, Jeong HJ, Chung GT, Yoo C-K, Kang Y-H, Lee DY (2015) Occurrence of norovirus GII.4 Sydney variant-related outbreaks in Korea. Osong Public Health Res Perspect 6(5):322-326

Kim SH, Cheon DS, Kim JH, Lee DH, Jheong W, Heo YJ, et al (2005) Outbreaks of gastroenteritis that occurred during school excursions in Korea were associated with several waterborne strains of norovirus. J Clinical Microbiol 43(9):4836-4839

Koch T (2013) Commentary: the researcher as amateur: John Lea, cholera, and ... the computer age. Int J Epidemiol 42(1):52-58

Koh S-J, Cho HG, Kim BH, Choi BY (2011) An outbreak of gastroenteritis caused by norovirus-contaminated groundwater at a waterpark in Korea. J Korean Med Sci 26(1):28-32

Kreutzwiser R, de Loë R, Imgrund K, Conboy MJ, Simpson H, Plummer R (2011) Understanding stewardship behaviour: factors facilitating and constraining private water well stewardship. J Environ Manag 92(4):1104-1114

Kukkula M, Arstila P, Klossner ML, Maunula L, Bonsdorff CH, Jaatinen P (1997) Waterborne outbreak of viral gastroenteritis. Scand J Infect Dis 29(4):415-418

Kvitsand HML, Fiksdal L (2010) Waterborne disease in Norway: emphasizing outbreaks in groundwater systems. Water Sci Technol 61(3): 563

Lambertini E, Borchardt MA, Kieke BA, Spencer SK, Loge FJ (2012) Risk of viral acute gastrointestinal illness from nondisinfected drinking water distribution systems. Environ Sci Technol 46(17):9299_ 9307
Lapworth DJ, Stuart ME, Pedley S, Nkhuwa DCW, Tijani MN (2015) A review of urban and periurban groundwater quality studies in subSaharan Africa. British Geological Survey Draft Open Report OR/ 15/011. 133pp, (unpublished)

LeChevallier MW, Norton WD, Lee RG (1991) Occurrence of Giardia and Cryptosporidium spp. in surface water supplies. Appl Environ Microbiol 57(9):2610-2616

Lee H, Kim M, Lee JE, Lim M, Kim M, Kim JM, et al (2011) Investigation of norovirus occurrence in groundwater in metropolitan Seoul, Korea. Sci Total Environ 409(11):2078-2084

Lee SH, Levy DA, Craun GF, Beach MJ, Calderon RL (2002) Surveillance for waterborne-disease outbreaks: United States, 1999-2000. Retrieved from http://www.cdc.gov/mmwr/PDF/ss/ ss5108.pdf. Accessed August 21, 2016

Lewallen S, Courtright P (1998) Epidemiology in practice: case-control studies. Commu Eye Health 11(28):57-58

Lopman B, Gastañaduy P, Park GW, Hall AJ, Parashar UD, Vinjé J (2012) Environmental transmission of norovirus gastroenteritis. Curr Opin Virol 2(1):96-102

Macdonald AM, Calow RC, Macdonald DMJ, Darling WG, Dochartaigh BÉÓ (2009) What impact will climate change have on rural groundwater supplies in Africa? Hydrol Sci J 54(4):690-703

Macler BA, Merkle JC (2000) Current knowledge on groundwater microbial pathogens and their control. Hydrogeol J 8(1):29-40

Margat J, van der Gun J (2013) Groundwater around the World. CRC Press/Balkema

Marshall MM, Naumovitz D, Ortega Y, Sterling CR (1997) Waterborne protozoan pathogens. Clin Microbiol Rev 10(1):67-85

Maurer AM, Stürchler D (2000) A waterborne outbreak of small round structured virus, Campylobacter and Shigella co-infections in La Neuveville, Switzerland, 1998. Epidemiol Infect 125:325-332

Medema GJ, Shaw S, Waite W, Snozzi M, Morreau A, Grabow W (2003) Catchment characteristics and source water quality. In: Assessing microbial safety of drinking water: improving approaches and method. WHO and OECD, IWA, London, pp 111-158

Mena KD, Gerba CP (2009) Waterborne adenovirus. Rev Environ Contam Toxicol 198:133-167

Messner M, Shaw S, Regli S, Rotert K, Blank V, Soller J (2006) An approach for developing a national estimate of waterborne disease due to drinking water and a national estimate model application. J Water Health 4(Suppl 2):201-240

Miettinen IT, Zacheus O, von Bonsdorff CH, Vartiainen T (2001) Waterborne epidemics in Finland in 1998-1999. Water Sci Technol 43(12):67-71

Migliorati G, Prencipe V, Ripani A, Di Francesco C, Casaccia C, Crudeli S, et al (2008) Gastroenteritis outbreak at holiday resort, central Italy. Emerging Infectious Dis 14(3):474-478

Moore AC (1993) Surveillance for waterborne disease outbreaks: United States, 1991-1992. Retrieved from http://www.cdc.gov/mmwr/ preview/mmwrhtml/00025893.htm. Accessed August 15, 2016

Muhamad Harish S, Sim K-S, Najimudin N, Aziah I (2015) Genome sequence of Salmonella enterica subsp. enterica serovar typhi isolate PM016/13 from untreated well water associated with a typhoid outbreak in Pasir Mas, Kelantan, Malaysia. Genome Announc 3(6): e01261-15. doi:10.1128/genomeA.01261-15

Mukherjee A, Sengupta MK, Hossain MA, Ahamed S, Das B, Nayak B, et al (2006) Arsenic contamination in groundwater: a global perspective with emphasis on the Asian scenario. J Health Population Nutrition 24(2):142-163

Murata T, Katsushima N, Mizuta K, Muraki Y, Hongo S, Matsuzaki Y (2007) Prolonged norovirus shedding in infants $\leq 6$ months of age with gastroenteritis. Pediatr Infect Dis J 26(1):46-49. doi:10.1097/ 01.inf.0000247102.04997.e0

Murphy HM, Pintar KDM, McBean EA, Thomas MK (2014) A systematic review of waterborne disease burden methodologies from 
developed countries. J Water Health 12(4):634. doi:10.2166/wh. 2014.049

Murphy HM, Thomas MK, Medeiros DT, McFayden S, Pintar KDM (2016a) Estimating the number of cases of acute gastrointestinal illness (AGI) associated with Canadian municipal drinking water systems. Epidemiol Infect 144(7):1371-1385. doi:10.1017/ S0950268815002083

Murphy HM, Thomas MK, Schmidt PJ, Medeiros DT, McFadyen S, Pintar KDM (2016b) Estimating the burden of acute gastrointestinal illness due to Giardia, Cryptosporidium, Campylobacter, E. coli $\mathrm{O} 157$ and norovirus associated with private wells and small water systems in Canada. Epidemiol Infect 144(7):1355-1370. doi:10. 1017/S0950268815002071

O'hAiseadha CO, Hynds PD, Fallon UB, O'Dwyer J (2017) A geostatistical investigation of agricultural and infrastructural risk factors associated with primary verotoxigenic E. coli (VTEC) infection in the Republic of Ireland, 2008-2013. Epidemiol Infect 145(1): 95

Ogorzaly L, Bertrand I, Paris M, Maul A, Gantzer C (2010) Occurrence, survival, and persistence of human adenoviruses and F-specific RNA phages in raw groundwater. Appl Environ Microbiol 76(24): 8019-8025. doi:10.1128/AEM.00917-10

Pagaya J, Massi N, Limmon GL, Natsir R (2015) Detection of flaA virulence genes Campylobacter jejuni, isolated from human faeces and groundwater using PCR method. Int J Curr Microbiol App Sci 4(6):379-387

Parashar UD, Alexander JP, Glass RI. (2006) Prevention of Rotavirus Gastroenteritis among Infants and Children. MMWR Recommendations and Reports. 55(RR12); 1-13

Park J-H, Jung S, Shin J, Lee JS, Joo IS, Lee D-Y (2015) Three gastroenteritis outbreaks in South Korea caused by the consumption of kimchi tainted by norovirus GI.4. Foodborne Pathog Dis 12(3): 221-227. doi:10.1089/fpd.2014.1879

Parshionikar SU, Willian-True S, Fout GS, Robbins DE, Seys SA, Cassady JD, Harris R (2003) Waterborne outbreak of gastroenteritis associated with a norovirus. Appl Environ Microbiol 69(9):52635268. doi:10.1128/AEM.69.9.5263-5268.2003

Raina PS, Pollari FL, Teare GF, Goss MJ, et al (1999) The relationship between $E$. coli indicator bacteria in well-water and gastrointestinal illness in rural families. Can J Public Health 90(3):172-175

Rebaudet S, Sudre B, Faucher B, Piarroux R (2013) Environmental determinants of cholera outbreaks in inland Africa: a systematic review of main transmission foci and propagation routes. J Infect Dis 208(suppl 1):S46-S54. doi:10.1093/infdis/jit195

Reynolds KA, Mena KD, Gerba CP (2008) Risk of waterborne illness via drinking water in the United States. In: Reviews of environmental contamination and toxicology. Springer, Heidelberg, Germany, pp 117-158. doi:10.1007/978-0-387-71724-1 4

Rigotto C, Hanley K, Rochelle PA, De Leon R, Barardi CRM, Yates MV (2011) Survival of adenovirus types 2 and 41 in surface and ground waters measured by a plaque assay. Environ Sci Technol 45(9): 4145-4150. doi:10.1021/es103922r

Risebro HL, Hunter PR, Doria MF, Andersson Y, Medema G, Osborn K, Schlosser O (2007) Fault tree analysis of the causes of waterborne outbreaks. J Water Health 5(Suppl 1):S1. doi:10.2166/wh.2007.136

Ritter KS, Sibley L (2002) Sources, pathways, and relative risks of contaminants in surface water and groundwater: a perspective prepared for the Walkerton inquiry. J Toxic Environ Health A 65(1):1142.doi: $10.1080 / 152873902753338572$

Rose JB (1997) Environmental ecology of cryptosporidium and public health implications. Annu Rev Public Health 18(1):135-161. doi: 10.1146/annurev.publhealth.18.1.135

Rosen B (2000) Waterborne pathogens in agricultural watersheds. Natural Resource, Agriculture, and Engineering Service (NRAES) Cooperative Extension, USDA, Natural Resources Conservation Service, and Watershed Science Institute, Ithaca, (NRAES- 147)
Rothman KJ (2012) Epidemiology: an introduction, 2nd edn. Oxford University Press, New York

Schijven JF, Hassanizadeh SM, de Roda Husman AM (2010) Vulnerability of unconfined aquifers to virus contamination. Water Res 44(4):1170-1181

Schuster CJ, Ellis AG, Robertson WJ, Charron DF, Aramini JJ, Marshall BJ, Medeiros DT (2005) Infectious disease outbreaks related to drinking water in Canada, 1974-2001. Can J Public Health 96(4): 254-258

Seward JF, Marin M, Vázquez M (2008) Varicella vaccine effectiveness in the US vaccination program: a review. J Infect Dis 197(Suppl 2): S8

Sobsey MD, Hall RM, Hazard RL (1995) Comparative reductions of hepatitis a virus, enteroviruses and coliphage MS2 in miniature soil columns. Health-Related Water Microb 1994 31(5):203-209. doi: 10.1016/0273-1223(95)00267-Q

Smith HV, Rose JB (1998) Waterborne cryptosporidiosis: current status. Parasitol Today 14:14-22

Statistics Canada (2013) Households and the Environment Survey 2011. Statistics Canada, Ottawa

Steyer A, Torkar KG, Gutiérrez-Aguirre I, Poljšak-Prijatelj M (2011) High prevalence of enteric viruses in untreated individual drinking water sources and surface water in Slovenia. Int J Hyg Environ Health 214(5):392-398. doi:10.1016/j.ijheh.2011.05.006

St-Pierre K, Levesque S, Frost E, Carrier N, Arbeit RD, Michaud S (2009) Thermotolerant coliforms are not a good surrogate for Campylobacter spp. in environmental water. Appl Environ Microbiol 75(21):6736-6744. doi:10.1128/AEM. 00486-09

Straub TM, Pepper IL, Gerba CP (1993) Hazards from pathogenic microorganisms in land-disposed sewage sludge. In: Reviews of environmental contamination and toxicology. Springer, New York, pp 55-91. doi:10.1007/978-1-4684-7065-9 3

Strauss B, King W, Ley A, Hoey JR (2001) A prospective study of rural drinking water quality and acute gastrointestinal illness. BMC Public Health 1(1):8. doi:10.1186/1471-2458-1-8

Szewzyk U, Szewzyk R, Manz W, Schleifer KH (2000) Microbiological safety of drinking water. Annu Rev Microbiol $54: 81-127$

Thomas MK, Murray R, Flockhart L, Pintar K, Pollari F, Fazil A, et al (2013) Estimates of the burden of foodborne illness in Canada for 30 specified pathogens and unspecified agents, circa 2006. Foodborne Pathogens Dis 10(7):639-648.doi:10.1089/fpd.2012.1389

Tissier A, Denis M, Hartemann P, Gassilloud B (2012) Development of a rapid and sensitive method combining a cellulose ester microfilter and a real-time quantitative PCR assay to detect Campylobacter jejuni and Campylobacter coli in 20 liters of drinking water or low-turbidity waters. Appl Environ Microbiol 78(3):839-845. doi: 10.1128/AEM.06754-11

Tulchinsky TH, Burla E, Clayman M, Sadik C, Brown A, Goldberger S (2000) Safety of community drinking-water and outbreaks of waterborne enteric disease: Israel, 1976-97. Bull World Health Org 78(12):1466-1473

Uhlmann S, Galanis E, Takaro T, Mak S, Gustafson L, Embree G, et al (2009) Where's the pump? Associating sporadic enteric disease with drinking water using a geographic information system, in British Columbia, Canada, 1996-2005. J Water Health 07(4):692. doi:10. 2166/wh.2009.108

US EPA (2008) Ground water rule: a quick reference guide-EPA-816-F08-029. Retrieved from http://nepis.epa.gov/Exe/ZyPDF.cgi? Dockey=P100156H.txt. Accessed August 15, 2016

US EPA (2015) Private drinking water wells. Retrieved from http:// www2.epa.gov/privatewells. Accessed August 15, 2016

van der Hoek W, Hunink J, Vellema P, Droogers P (2011) Q fever in The Netherlands: the role of local environmental conditions. Int $\mathrm{J}$ 
Environ Health Res 21(6):441-451. doi:10.1080/09603123.2011. 574270

Wallender EK, Ailes EC, Yoder JS, Roberts VA, Brunkard JM (2014) Contributing factors to disease outbreaks associated with untreated groundwater. Groundwater 52(6):886-897. doi:10.1111/gwat.12121

Whiley H, van den Akker B, Gidlio S, Bentham R (2013) The role of environmental reservoirs in human campylobacteriosis. Int $\mathrm{J}$ Environ Res Public Health 10(11):5886-5907

WHO (2010) Cholera, 2009. Wkly Epidemiol Rec 85(31):293-308

WHO/UNICEF Joint Water Supply and Sanitation Monitoring Programme (2015) Progress on sanitation and drinking water. UNICEF, New York

Wikswo ME, Hall AJ (2012) Outbreaks of acute gastroenteritis transmitted by person-to-person contact: United States, 2009-2010. Morb Mortal Wkly Rep Surveill Summ 61(9):1-12
Willocks L, Crampin A, Milne L, Seng C, Susman M, Gair R, et al (1998) A large outbreak of cryptosporidiosis associated with a public water supply from a deep chalk borehole. Communicable Dis Public Health 1(4):239-243

Yates MV, Gerba CP, Kelley LM (1985) Virus persistence in groundwater. Appl Environ Microbiol 49(4):778-781

Zheng DP, Widdowson MA, Glass RI, Vinjé J (2010) Molecular epidemiology of genogroup II-genotype 4 noroviruses in the United States between 1994 and 2006. J Clin Microbiol 48(1):168-177

Zmirou-Navier D, Gofti-Laroche L, Hartemann P (2006) Waterborne microbial risk assessment: a population-based dose-response function for Giardia spp. (E.MI.R.A study). BMC Public Health 6:122. doi:10.1186/1471-2458-6-122 